OPEN ACCESS

Edited by:

Reinaldo B. Oria,

Federal University of Ceara, Brazil

Reviewed by:

Olli Peltoniemi,

University of Helsinki, Finland

Zhiyong Fan,

Hunan Agricultural University, China

*Correspondence:

Man Ren

renman@yeah.net

Shihai Zhang

zhangshihai@scau.edu.cn

Specialty section:

This article was submitted to

Nutritional Immunology,

a section of the journal

Frontiers in Immunology

Received: 14 August 2021 Accepted: 20 December 2021

Published: 21 January 2022

Citation:

Li Q, Yang S, Zhang X, Liu X, Wu Z, Qi Y, Guan W, Ren $M$ and Zhang $S$ (2022) Maternal Nutrition During Late Gestation and Lactation: Association With Immunity and the Inflammatory

Response in the Offspring.

Front. Immunol. 12:758525. doi: 10.3389/fimmu.2021.758525

\section{Maternal Nutrition During Late Gestation and Lactation: Association With Immunity and the Inflammatory Response in the Offspring}

\author{
Qihui $\mathrm{Li}^{1}$, Siwang Yang ${ }^{1}$, Xiaoli Zhang ${ }^{1}$, Xinghong Liu $^{1}$, Zhihui $W{ }^{1}{ }^{1}$, Yingao Qi ${ }^{1}$, \\ Wutai Guan ${ }^{1,2,3}$, Man Ren ${ }^{4 *}$ and Shihai Zhang ${ }^{1,2,3^{*}}$ \\ 1 Guangdong Provincial Key Laboratory of Animal Nutrition Control, College of Animal Science, South China Agricultural \\ University, Guangzhou, China, ${ }^{2}$ College of Animal Science and National Engineering Research Center for Breeding Swine \\ Industry, South China Agricultural University, Guangzhou, China, ${ }^{3}$ Guangdong Laboratory for Lingnan Modern Agriculture, \\ South China Agricultural University, Guangzhou, China, ${ }^{4}$ College of Animal Science, Anhui Science and Technology \\ University, Anhui Provincial Key Laboratory of Animal Nutritional Regulation and Health, Fengyang, China
}

The immature immune system at birth and environmental stress increase the risk of infection in nursing pigs. Severe infection subsequently induces intestinal and respiratory diseases and even cause death of pigs. The nutritional and physiological conditions of sows directly affect the growth, development and disease resistance of the fetus and newborn. Many studies have shown that providing sows with nutrients such as functional oligosaccharides, oils, antioxidants, and trace elements could regulate immunity and the inflammatory response of piglets. Here, we reviewed the positive effects of certain nutrients on milk quality, immunoglobulin inflammatory response, oxidative stress, and intestinal microflora of sows, and further discuss the effects of these nutrients on immunity and the inflammatory response in the offspring.

Keywords: maternal nutrition, neonate, growth, disease resistance, inflammatory, immunoglobulin

\section{INTRODUCTION}

During gestation and lactation, maternal nutrition is a predominant factor to regulate the growth and immunity of piglets $(1,2)$. Since neonates are born without brown fat reserves, timely intake of colostrum is the guarantee of energy supply for piglets. In addition, colostrum also provides bioactive molecules such as immunoglobulins and inflammatory factors to piglets (3). Even though maternal immunoglobulins cannot cross the placental barrier (4), these immunoglobulins could transfer to piglets through colostrum and milk (5). Maternal diets regulate the composition of colostrum and milk, which further affect the maturation of immune system in neonates (6). Furthermore, maternal milk-derived cytokines also regulate the immunity of neonates (6). It is worth noting that maternal intestinal microflora play a crucial role in regulation of immune development and response during the neonatal period (7). Transferring the intestinal flora of sows during pregnancy into sterile mice improved the intestinal innate immunity and reduced the inflammatory response in their offspring (8). Interestingly, newborn intestinal bacteria is derived from maternal microbiota during delivery and lactation (9). Thus, the regulation of maternal 
intestinal microflora by nutrients indirectly affect the offspring immunity and inflammatory response.

Maternal infection or inflammatory exposure during pregnancy impairs the innate response of newborns and increases their susceptibility to infection (10). During pregnancy, sows undergo dramatic changes of physiological metabolism and immunity (11), with markedly increased oxidative stress and inflammatory response (12). Imbalanced inflammatory response are closely related to reproductive disorders, including constipation, abortion and intrauterine growth retardation (9). In addition, inflammatory factors could transfer from maternal to fetus and regulate immunity and inflammatory response. Thus, modification of dietary components of sows during pregnancy might affect neonate intestinal development, immunity, and inflammation. In this review, we summarized the recently published data regarding prebiotic and nutrient supplementation to sow diets during late gestation (mainly during G85-G114) and lactation on maternal milk quality, inflammatory response, oxidative stress and then discuss their effect on the inflammatory response and immunity in the offspring.

\section{SOLUBLE DIETARY FIBER}

As indigestible carbohydrate, dietary fiber (DF) is partially or completely fermented by microorganisms in the large intestine, which could be categorized into insoluble and soluble fiber (13). Insoluble fiber speeds up the intestinal circulation, reduces constipation and increases the intestinal volume (14). While soluble fiber is fermented to produce numerous functional metabolites, such as short-chain fatty acids (SCFAs), which could be transmitted from maternal to offspring. Among them, acetate regulates intestinal permeability and anti-inflammatory effect (15). Butyrate improves intestinal morphology, promotes beneficial bacterial growth, and enhances immune defense $(16,17)$. It has also been shown that maternal DF supplementation could promote $\mathrm{T}$ cell differentiation and reduce the inflammatory response in the offspring by regulating the intestinal microbial composition (18). In this review, we focused on the effects of several representative DF supplementation in sow diets (Table $\mathbf{1}$ and Figure 1).

Isomaltooligosaccharide (IMO) has been reported to activate the immune system (27) and promotes the proliferative potential of beneficial bacteria (particularly Bifidobacterium) of sows (28). A recent study reported that feeding sow IMO during late pregnancy (G85-G110) could promote milk GH, IgA and IgG concentrations, increase litter average daily gain (ADG) of piglets, and reduce backfat loss in sow during lactation (19). Similarly, another study showed that IMO given to sows during late pregnancy increased the concentration of IgA, IgG and IgM in colostrum and reduced the diarrhea rate of piglets (29).

Chitosan oligosaccharide (COS) has good water solubility and performs antioxidant (30), anti-inflammatory (31), and immunity-enhancing functions (32). During gestation and lactation (G85-L21), sows given to COS (100 mg/kg) have higher milk production as well as IgM and lactose concentration in colostrum. In addition, COS (100 mg/kg) increased total number of piglets born and weaning weight per litter (20). Importantly, feeding sows with $30 \mathrm{mg} / \mathrm{kg}$ or $100 \mathrm{mg} / \mathrm{kg}$ COS both increase the serum IgG concentration of piglets, which indicates the enhancement of immune function in neonates $(26,33)$.

Sugar peat pulp (SBP) contains large amounts of soluble fibers such as pectin and dextran (34). Feeding SBP could increase the feed intake of sows during lactation by improving insulin sensitivity, which is beneficial to the serum GH and IGF-1 levels and growth of piglets (35). SBP supplementation $(20 \%$ during gestation and $10 \%$ during lactation) reduced proinflammatory cytokines (IL-6 and TNF- $\alpha$ ) in serum of sow. Consistently, pro-inflammatory cytokines (IL-6 and TNF- $\alpha$ ) in colostrum, milk and piglet serum are also decreased. Moreover, SBP supplementation in sow diet increase intestinal SCFA and colostral IgA levels, which might be beneficial for reducing inflammatory response in piglets (21).

Seaweed extracts (SWEs) mainly consists of seaweed polysaccharide (SDP), laminarin, and fucoidan (36). Supplementation with SWEs from late gestation to weaning increased colostrum IgG and IgA concentrations. Correspondingly, higher serum IgG concentrations were observed in piglets, which indicates the increased immune function (23). Sudden weaning of piglets is often accompanied by adverse morphological changes in the structure of the small intestine, including villous atrophy and crypt hyperplasia (37). Recent studies have shown the addition of seaweedderived polysaccharides $(10 \mathrm{~g} / \mathrm{d})$ to sow feed significantly increased the $\mathrm{VH}$ and ratio of villi/crypt (VH:CD) of weaned piglets. In addition, maternal SWE supplementation increases antiinflammatory (TGF- $\beta 1$ ) and inhibits pro-inflammatory factors (IL6 and IL-8) in the ileum and colon of piglets. Accordingly, the diarrhea score of the piglets during lactation was decreased (22). Furthermore, SWEs diet reduced the number of Enterobacteriaceae in sow feces at delivery and the number of Escherichia coli in piglet feces at weaning (38). These benefits might be attributed to laminarin could agglutinate certain pathogens and inhibit their adhesion to mucosal epithelial surfaces (39).

Guar gum is a kind of galactomannan extracted from guar endosperm. It has high viscosity and water solubility, which is widely used as a stabilizer and thickener in foods (40). Feeding $2.0 \%$ guar gum diet to sow during the gestation and lactation period (G85-L21) could improve the intestinal barrier function, accelerate the growth and reduce the diarrhea rate of piglets. In addition, guar gum increases the abundance of Lactobacilli and decrease the abundance of Bilophila spp in intestine. Importantly, IL-10 and TGF- $\beta$ levels were increased in piglets, which avoids over-activated immune system in piglets (24).

Mannan oligosaccharide (MOS), derived from the cell wall of Saccharomyces cerevisiae, has been used as a prebiotic for a long time (41). Recent supplementation of MOS in sow diets has been reported to regulate immunity and the inflammatory response in the offspring. Compared with the control treatment, MOS treatment $(400 \mathrm{mg} / \mathrm{kg})$ shortened the weaning estrous of the sows and increased the weaning weight of the piglets. Besides, sows fed MOS increased IgA, IgG, IgM in colostrum, and serum IgA and IgG levels in suckling piglets (25). Additionally, another study shows that the addition of MOS $(400 \mathrm{mg} / \mathrm{kg}$ ) to sow diet could significantly 
TABLE 1 | Maternal microbial and soluble dietary fiber intake in the regulation of neonatal infection, immunity and production performance.

\begin{tabular}{|c|c|c|c|c|c|}
\hline $\begin{array}{l}\text { Breed, feeding time } \\
\text { and products }\end{array}$ & $\begin{array}{l}\text { Reproductive and } \\
\text { lactation performance }\end{array}$ & $\begin{array}{l}\text { Immune and oxidative } \\
\text { stability of sows and piglets }\end{array}$ & $\begin{array}{l}\text { Intestinal health and } \\
\text { inflammation }\end{array}$ & Others & References \\
\hline $\begin{array}{l}\text { Breed: Large White } \times \\
\text { Landrace } \\
\text { period: G85-G110 } \\
\text { Product: } \\
\text { isomaltooligosaccharide } \\
5.0 \mathrm{~g} / \mathrm{kg} \mathrm{IMO} \\
0.2 \mathrm{~g} / \mathrm{kg} \mathrm{B} \text {. subtilis } \\
0.2 \mathrm{~g} / \mathrm{kg} \mathrm{B} \text {. } \\
\text { licheniformis }\end{array}$ & $\begin{array}{l}\text { Reproductive performance } \\
\text { } \text { weaning BW }(45.63-55.18 \mathrm{~kg}) \\
\text { Average litter gain }(28.43-35.87 \mathrm{~kg}) \\
\text { Milk } \\
\uparrow T \text { Total milk yield }(113.73-143.46 \mathrm{~kg}) \\
\operatorname{lgM}(1794.18-1894.73 \mathrm{~g} / \mathrm{mL}) \\
\text { on L0 } \\
\text { IgA ( } 607.50-922.07 \mathrm{~g} / \mathrm{mL}) \\
\text { on L17 }\end{array}$ & $\mathbf{N} / \mathbf{A}$ & N/A & $\begin{array}{l}\text { Sow plasma (L17) } \\
\downarrow \text { ALT (37.23-35.49 U/L) } \\
\text { ALP (40.23-31.82 U/L) }\end{array}$ & (19) \\
\hline $\begin{array}{l}\text { Breed: Yorkshire } \\
\text { period: G85-L21 } \\
\text { Product:chitosan } \\
\text { oligosaccharide } \\
(100 \mathrm{mg} / \mathrm{kg} \text { COS) }\end{array}$ & 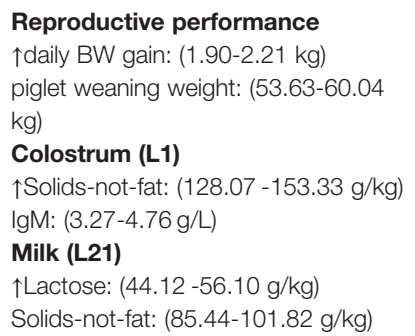 & 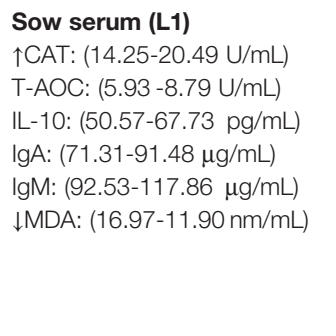 & N/A & N/A & (20) \\
\hline $\begin{array}{l}\text { Breed: Yorkshire } \times \\
\text { Landrace } \\
\text { Period: G85-L21 } \\
\text { (weaning) } \\
\text { Product: Sugar beet } \\
\text { pulp (SBP) } \\
20 \% \text { SBP in gestation } \\
\text { and } 10 \% \text { SBP in } \\
\text { lactation }\end{array}$ & $\begin{array}{l}\text { Piglet at weaning (L21) } \\
\uparrow \text { Litter weight: }(56.94-64.39 \mathrm{~kg}) \\
\text { Weaning weight: ((5.74-6.26 kg) } \\
\text { ADG: }(196-221 \mathrm{~g} / \mathrm{d}) \\
\text { Colostrum (L1) } \\
\uparrow l g A:(7.94-9.17 \mathrm{~g} / \mathrm{L})\end{array}$ & $\begin{array}{l}\text { Piglet serum (L21) } \\
\text { \DAO: (5.68-3.60 U/L) } \\
\text { Endotoxin: (0.60-0.47 EU/ml) } \\
\text { IL-6: (178.49-154.30 pg/mL) } \\
\text { TNF- } \alpha:(102.45-80.28 \mathrm{pg} / \mathrm{mL}) \\
\uparrow I L-10:(4.55-5.13 \mathrm{pg} / \mathrm{mL}) \\
\text { Piglet ileum (L21) } \\
\downarrow \text { TNF- } \alpha:(1-0.6) \\
\text { IL-6: (1-0.6) } \\
\uparrow I L-10:(1-1.3) \\
\text { SlgA: }(0.8-1.5 \mu \mathrm{g} / \mathrm{mg})\end{array}$ & $\begin{array}{l}\text { Piglets Ileal Tight } \\
\text { Junction (L21) mRNA } \\
\text { expression } \\
\uparrow O c c l u d i n g:(1-1.3) \\
\text { ZO-1: (1-1.4) } \\
\text { Piglet Jejunum } \\
\uparrow \text { Villus height: (387-447 } \mu \mathrm{m}) \\
\text { Intestinal microbiota } \\
\text { (Piglet) } \\
\text { the relative abundance of } \\
\text { Christensenellaceae was } \\
\text { increased significantly }\end{array}$ & $\begin{array}{l}\uparrow \text { Sow ADFI: (4.80-5.48 } \\
\text { kg/d) } \\
\text { Piglet serum (L21) } \\
\uparrow G H:(3.37-4.23) \\
\text { IGF-1(156.09-187.86) }\end{array}$ & (21) \\
\hline $\begin{array}{l}\text { Breed: Yorkshire } \times \\
\text { Landrace } \\
\text { Period: G83-L28 } \\
\text { (weaning) } \\
\text { Product: seaweed- } \\
\text { derived } \\
\text { polysaccharides }(10.0 \mathrm{~g} \\
\text { SDP/d) }\end{array}$ & †gestation period: (113.5-114.5 d) & 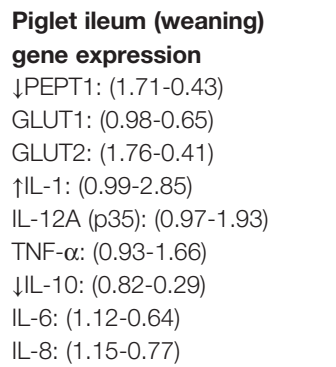 & 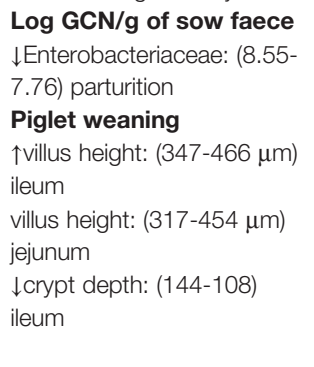 & $\begin{array}{l}\text { Piglets had a lower } \\
\text { diarrhoea score during } \\
\text { the lactation period }\end{array}$ & $(22)$ \\
\hline $\begin{array}{l}\text { Breed: Large White x } \\
\text { Landrace } \\
\text { Period: G107-L26 } \\
\text { Product: seaweed } \\
\text { extract (10 g/d) }\end{array}$ & $\begin{array}{l}\text { Colostrum } \\
\uparrow \operatorname{lgA}:(8.02-11.61 \\
\mathrm{mg} / \mathrm{mL})\end{array}$ & $\begin{array}{l}\text { Piglet serum (L14) } \\
\text { †lgG: (8.59-11.36 mg/ml) }\end{array}$ & 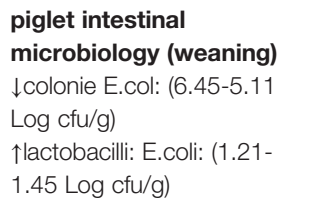 & $\begin{array}{l}\text { log cfu/g of sow feces } \\
\text { (farrowing) } \\
\downarrow \text { En-terobacteriacea: } \\
(8.60-7.26)\end{array}$ & (23) \\
\hline $\begin{array}{l}\text { Breed: Landrace sows } \\
\text { Period: G85-L21 } \\
\text { (weaning) } \\
\text { Product: } 2.0 \% \\
\text { pregelatinized waxy } \\
\text { maize starch plus guar } \\
\text { gum (SF) }\end{array}$ & $\begin{array}{l}\text { Piglet at weaning (L21) } \\
\uparrow F i n a l ~ B W:(6.49-7.09 \mathrm{~kg}) \\
\text { ADG: }(233.66-261.20 \mathrm{~g} / \text { day) }\end{array}$ & $\begin{array}{l}\text { Piglet serum (L14) } \\
\text { لIL-6: (310-290 pg/ml) } \\
\uparrow T G F-\beta:(650-750 \mathrm{pg} / \mathrm{ml}) \\
\text { IL-10: (110-140 pg/ml) }\end{array}$ & $\begin{array}{l}\text { Piglet plasma (L14) } \\
\downarrow \text { Zonulin: (700-550 ng/ml) } \\
\text { Endotoxin: (0.7-0.5 Eu/ml) } \\
\text { Diamine oxidase: (10-9 U/L) } \\
\downarrow \text { lipocalin-2 (80-58 } \mathbf{g} / \mathbf{g} \\
\text { feces) } \\
\text { Intestinal microbiota } \\
\text { (Piglet) } \\
\text { strong increase in relative } \\
\text { abundance of the } \\
\text { Lactobacillus genus }\end{array}$ & $\begin{array}{l}\text { Piglet Diarrhea rate: } \\
(13.69-10.35 \%) \\
\text { plasma hormone of } \\
\text { piglets (L14) } \\
\uparrow \mathrm{GH}:(587.65-657.49 \mathrm{pg} / \\
\mathrm{ml}) \\
\text { IGF-1: (309.04-374.63 } \\
\mathrm{ng} / \mathrm{ml})\end{array}$ & (24) \\
\hline
\end{tabular}


TABLE 1 | Continued

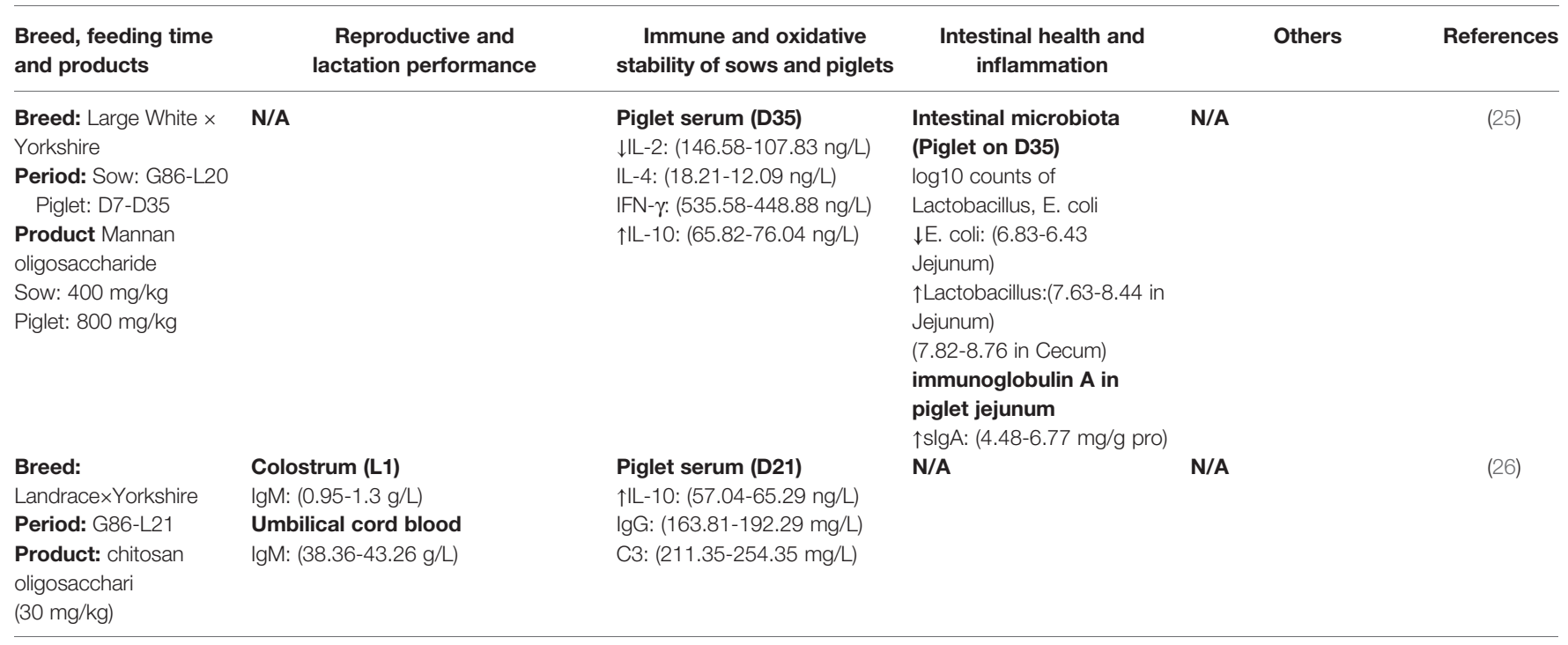

$\uparrow$, increase; $\downarrow$, decrease; N/A, No Value; BW, body weight; IgA, Immunoglobulin A; IgG, Immunoglobulin G; IgM, Immunoglobulin M; T- AOC, Total antioxidant capacity; CAT, Catalase; MDA, Malondialdehyde; IL-10, interleukin 10; IL-6, interleukin 6; IL-8, interleukin 8; IL-4, interleukin 4; IL-2, interleukin 2; TNF- $\alpha$, tumor necrosis factor- $\alpha$; GH, growth hormone; IGF-1, insulin like growth factor 1; ZO-1, zonula occludens-1; ALT, cereal third transaminase; ALP, alkaline phosphatase; ADG, average daily gain; PEPT1, peptide-transporters 1; GLUT1, glucose transporter-1; GLUT2, glucose transporter-2; TGF- $\beta$, transforming growth factor $\beta$; IFN- $\gamma$, interferon- $\gamma$, C3, complement 3; slgA, secretedimmunoglobulin A.

increase the sIgA content in jejunum mucosa and reduce the intestinal inflammatory response of piglets by inhibiting the TLR2/TLR4/NF- $\mathrm{KB}$ p65 pathway. Furthermore, MOS supplementation in sow diet increased the number of Lactobacilli and decreased the number of Escherichia coli in the jejunum of piglets, which is beneficial for reducing diarrhea (42).

Besides soluble fiber, insoluble dietary fiber also plays a crucial physiology role in sow. Insoluble dietary fiber accelerates gastrointestinal motility, reduces constipation and increases satiety of sows (43). Wheat bran (WB) is a insoluble fiber rich in arabinoxylan and cellulose, and widely used in the sow diet (44). A recent study showed that feeding WB to sows during late pregnancy and lactation (from G110 and L21) reduced inflammatory responses with the downregulation of serum IL-6 concentrations (21). In addition, the addition of wheat bran (25\% during gestation and $14 \%$ during lactation) to sow diets increase the duodenal villi and higher colonic and ileal VH:CD ratios of the weaning piglets (45).

However, excessive level of dietary fiber could negatively affect total tract nutrient digestibility in pigs (46). As soluble fiber might increase digesta viscosity and slow down the diffusion of digestive enzymes in the small intestine (47). While insoluble fiber could promote the passage rate of chyme and reduce the mixing time of digestive enzymes and dietary ingredients (47). Therefore, overmuch high-fiber diet may cause reduced nutrient absorption by sows, which is detrimental to piglets. And the optimal dosage of fiber supplement in the diet of gestational sows needs further study.

\section{OILS}

During late pregnancy and lactation period, sows require more nutrients and energy for fetal growth and milk synthesis. Oil supplementation in sow diets could prevent excessive mobilization of body reserves (48), shorten the estrous interval, improve milk quantity (49), and increase the survival rate and daily weight gain of weaned piglets (50). In addition, some specific types of fatty acids also participate in metabolic regulation and perform antibacterial and anti-inflammatory effects (51). In this section, we discussed the role of three wildly used oils (soybean oil, fish oil and olive oil) in sow diet.

Soybean oil is rich in linoleic acid. The addition of $2 \%$ soybean oil during pregnancy increased the content of protein and lipid-free solids in colostrum (Table 2). Furthermore, supplementation of soybean oil in the lactating diets of sows also resulted in higher concentrations of protein in maternal milk (54), which may be due to fatty acids stimulate the development of mammary duct and alveolar structure (55). In addition, maternal soybean oil supplementation also improved the intestinal morphology, digestive enzyme activities, serum growth factor concentrations and even intestinal immune function of piglets with the upregulation of immune-related genes (TLR-4, TLR-9 and MyD88) in the ileum $(52,56)$.

Fish oil (FO) is rich in long-chain n-3 polyunsaturated fatty acids, such as eicosapentaenoic acid (EPA) and docosahexaenoic acid (DHA), which have anti-inflammatory effects both in vivo and in vitro (57) (Figure 2). Maternal supplementation of FO accelerated immune system maturation and enhanced antiinflammatory response of piglet (58). The addition of 3-5\% fish oil to sow feed during lactation promoted the growth of piglets during lactation (59-61), which might partly due to the increased secretion of milk fat and immunoglobulins (IgM and $\operatorname{IgG})(62,63)$. Furthermore, fish oil also reduced the transmission of pro-inflammatory cytokines (IL-1 $\beta$ ) from the sow to the piglets, and up-regulated the expression of IL-10 in the liver and pro-inflammatory cytokines (IL-6, TNF- $\alpha$ ) in the skeletal muscle of piglets to alleviate the inflammatory response of the 


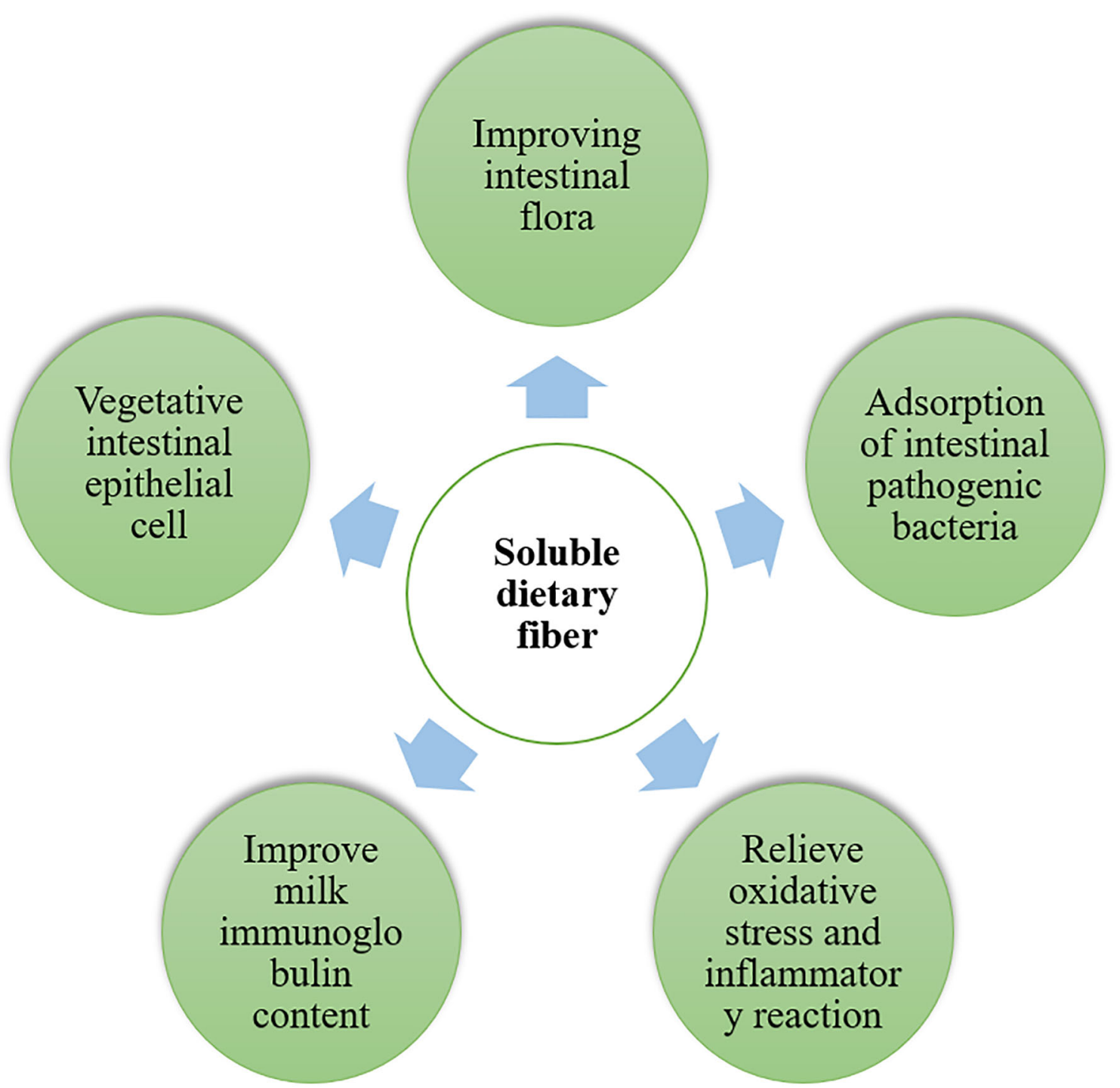

FIGURE 1 | The soluble dietary fibers beneficial to intestinal health of sow, improves colostrum quality, enhance antioxidant capacity of sows and reduces inflammatory reaction of piglets.

piglets $(64,65)$. However, addition of fish oil to sow diets could increase the sensitivity to oxidative stress in sows and piglets (66, 67). MDA is an indicator of lipid peroxidation, which is higher in the plasma of pregnant sows after feeding FO (53). This might due to unsaturated bonds in EPA and DHA were easily attacked by free radicals (68). Similar to fish oil supplementation, addition of n-3 PUFA during late pregnancy and lactation (G82-L22) reduced the weaning-estrous interval of sows, increased the concentrations of fat, protein and immunoglobulins (IgA, IgG and IgM) in milk (69). Furthermore, n-3 PUFA supplementation improved the intestinal barrier, reduced the diarrhea rate, and minimized the mortality of suckling piglets (69). Besides, changing the ratio of $n-6 / n-3$ PUFA in the diet of lactating sows also affect the immune system and antioxidant status of piglets $(70,71)$.
Olive oil (OO) is rich in monounsaturated fatty acids (72), as well as antioxidant and anti-inflammatory components such as tocopherols, triterpenoid alcohols, phytosterols and phenolic compounds (73). Sows fed with olive oil (2\% OO) diet during late pregnancy and lactation resulted in greater milk fat content, and higher birth weight and survival rate of piglets (53). This might be due to sows distributed a larger proportion of nutrients for fetus and neonate growth instead of using them for fat deposition. In addition, OO significantly reduced the contents of IL-1 $\beta$, IL-6, MDA and TNF- $\alpha$ in milk, and improved the plasma levels of IL- $1 \beta$ and TNF- $\alpha$ in piglets (53). However, lower feed intake in sows was caused by $\mathrm{OO}$ feeding, which might be due to olive oil derived oleic acid upregulated plasma oleoyl ceramide (OEA) levels and caused anorexia in sows (74). 
TABLE 2 | Maternal fats intake in the regulation of neonatal infection, immunity and production performance.

\begin{tabular}{|c|c|c|c|c|c|}
\hline $\begin{array}{l}\text { Breed, feeding time } \\
\text { and products }\end{array}$ & $\begin{array}{l}\text { Reproductive and } \\
\text { lactation performance }\end{array}$ & $\begin{array}{c}\text { immune and oxidative } \\
\text { Stability of sows and piglets }\end{array}$ & Intestinal health & others & References \\
\hline $\begin{array}{l}\text { Breed: Landrace } \times \\
\text { Yorkshire } \\
\text { Period: G0-L20 } \\
\text { Product: } 2 \% \\
\text { soybean oil }\end{array}$ & $\begin{array}{l}\text { Colostrum } \\
\uparrow \text { No-fat solids: (15.53-22.90\%) } \\
\text { Protein: (5.85-8.79\%) }\end{array}$ & $\begin{array}{l}\text { Piglet ileum (After } \\
\text { farrowing) Gene } \\
\text { Expression } \\
\text { } T \text { TLR-4: }(1.00-1.48) \\
\text { TLR-9: }(1.00-1.40) \\
\text { MyD8: }(1.00-1.22)\end{array}$ & $\begin{array}{l}\text { Piglet Jejunum (After } \\
\text { farrowing) } \\
\uparrow \text { Villous height: }(717-923 \mu \mathrm{m}) \\
\text { Crypt depth: }(76-88 \mu \mathrm{m}) \\
\text { Piglet Colon (After } \\
\text { farrowing) } \\
\uparrow \text { Crypt depth: }(32-41 \mu \mathrm{m}) \\
\downarrow \text { VCR: }(6.53-4.40) \\
\text { (villous height to crypt depth } \\
\text { ratio) }\end{array}$ & $\begin{array}{l}\text { Sow plasma (After } \\
\text { farrowing) } \\
\text { Prolactin: (262.00-432.70 } \\
\text { ng/mL) }\end{array}$ & (52) \\
\hline $\begin{array}{l}\text { Breed: Large White } \\
\times \text { Landrace } \\
\text { Period: G109- } \\
\text { weaning (L26) } \\
\text { Product: fish oil and } \\
\text { seaweed extract (100 } \\
\text { g of FO/d, } 10.0 \mathrm{~g} \text { of } \\
\text { SWE/d) }\end{array}$ & $\begin{array}{l}\text { Colostrum (SWE) } \\
\uparrow l g G:(63.27-69.84 \mathrm{mg} / \mathrm{ml}) \\
\text { Milk (L12) (SWE) } \\
\uparrow C P:(5.17-5.39 \%) \\
\text { Milk (L12) (FO) } \\
\uparrow \text { Total n-34: (1.73-4.62\%) } \\
\text { Ratio n-6:n-3: (9.75-3.80\%) }\end{array}$ & $\begin{array}{l}\text { Piglet serum (L5) } \\
\uparrow l g G(S W E):(19.31-22.9 \text { mg/ } \\
\text { ml) } \\
\text { lgA (SWE): }(2.51-3.13 \mathrm{mg} / \mathrm{ml}) \\
\downarrow l g A(F O):(3.12-2.52 \mathrm{mg} / \mathrm{ml}) \\
\text { Piglet serum (L12) } \\
\uparrow l g G(S W E):(9.98-12.04 \mathrm{mg} / \\
\text { ml) }\end{array}$ & N/A & $\begin{array}{l}\text { Piglet serum (L26) } \\
\uparrow T o t a l \text { n-6: (0.99-0.16\%) } \\
\text { Total n-3: (1.43-0.030\%) } \\
\text { Ratio n-6:n-3: (0.61- } \\
0.232 \%)\end{array}$ & (23) \\
\hline $\begin{array}{l}\text { Breed: large white } \times \\
\text { landrace } \\
\text { Period: G84-L21 } \\
\text { Product: Fish Oil } \\
\text { (2\%) } \\
\text { Or } \\
\text { Olive Oil (2\%) }\end{array}$ & 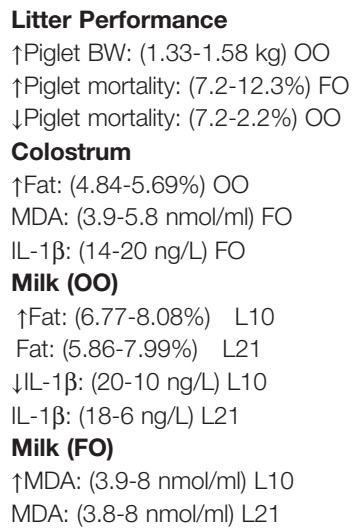 & $\begin{array}{l}\text { Sow plasma (FO) } \\
\uparrow M D A:(2-2.25 \mathrm{nmol} / \mathrm{ml}) \text { LO } \\
\text { MDA: }(2-3.5 \mathrm{nmol} / \mathrm{ml}) \text { L10 } \\
\text { MDA: }(1.5-2 \mathrm{nmol} / \mathrm{ml}) \text { L21 } \\
\text { Piglet serum (FO) } \\
\uparrow M D A:(2.75-4 \mathrm{nmol} / \mathrm{ml}) \text { LO } \\
\text { MDA: }(3-4 \mathrm{nmol} / \mathrm{ml}) \text { L21 } \\
\text { GSH-Px: }(275-300 \mathrm{U} / \mathrm{ml}) \text { LO } \\
\text { Piglet serum (OO) } \\
\text { لIL-1 } \beta:(12-10 \mathrm{ng} / \mathrm{L}) \text { L21 } \\
\text { TNF- } \alpha:(90-80 \mathrm{ng} / \mathrm{L}) \text { L21 }\end{array}$ & N/A & N/A & (53) \\
\hline
\end{tabular}

$\uparrow$, increase; $\downarrow$, decrease. N/A, No Value; TLR-4, toll-like receptor 4; TLR-9, toll-like receptor 9; MүD88, myeloiddifferentiationfactor88 IgG, Immunoglobulin G; IgA, Immunoglobulin A; IL-10, interleukin 10; TNF- $\alpha$, tumor necrosis factor- $\alpha$; MDA, malondialdehyde; IL-1 $\beta$, interleukin-1 $\beta ; T$ - AOC, total antioxidant capacity; GSH-PX, glutathione peroxidase IL-6, interleukin 6.

It is worth noting that high fat-induced obese sows have lower number of live-born piglets (75), piglet birth weight and weaning weight (76). Moreover, these piglets showed reduced responses to infection (77). One of the possible reasons is that obesity lead to lipotoxic placental environment $(78,79)$, which results in placenta proinflammatory response and oxidative stress $(80,81)$. The other reason is obese sow has higher plasma pro-inflammatory cytokines TNF- $\alpha$, IL-1 $\beta$, and IL-6 $(75,82)$. Maternal inflammation and oxidative stress further increase the expression of intestinal proinflammatory cytokines (83) and disrupts the homeostasis of immune cells (such as the number of T cells and macrophages) in the offspring (84), which makes them more vulnerable to inflammatory bowel disease. These data indicate that the excessive high-energy feed have catastrophic consequences for health of sows and piglets. Therefore, oil additive dosage should be considered in actual production.

\section{ANTIOXIDANTS}

During late pregnancy,rapid fetal development increases the metabolic burden and induces systemic oxidative stress of pregnant sows (85).Severe oxidative stress leads to postpartum hemorrhage, decreases neonate's birth weight and even causes fetal death (86). Furthermore, oxidative stress usually causes inflammation and reduces immune system function in sows, which leads to growth-retarded fetuses $(87,88)$. The detrimental effect of maternal infection or inflammation on fetus development might be due to maternal inflammatory cytokines that transmitted from maternal to fetus $(89,90)$. Therefore, nutritional strategies to relieve oxidative stress in sows is crucial to improve fetus and neonate development (Table 3).

Vitamin E, one of the most effective antioxidants, could directly react with free radicals and stimulate the expression of antioxidant enzyme genes, like GSH-Px and CAT (94). In addition, vitamin $\mathrm{E}$ enhances cellular and humoral immune responses in a variety of animals, including pigs $(98,99)$. During last week of gestation and lactation, vitamin E (250 IU/ $\mathrm{kg}$ ) supplementation in sow diet increased the levels of IgG, IgA, and fat in sow milk and enhanced antioxidant and immune capacity in piglets with the upregulation of plasma IgG, IgA, TAOC and CAT levels (94). Similarly, injection of 1000 IU vitamin E during gestation also increases serum IgG in sows (100). 


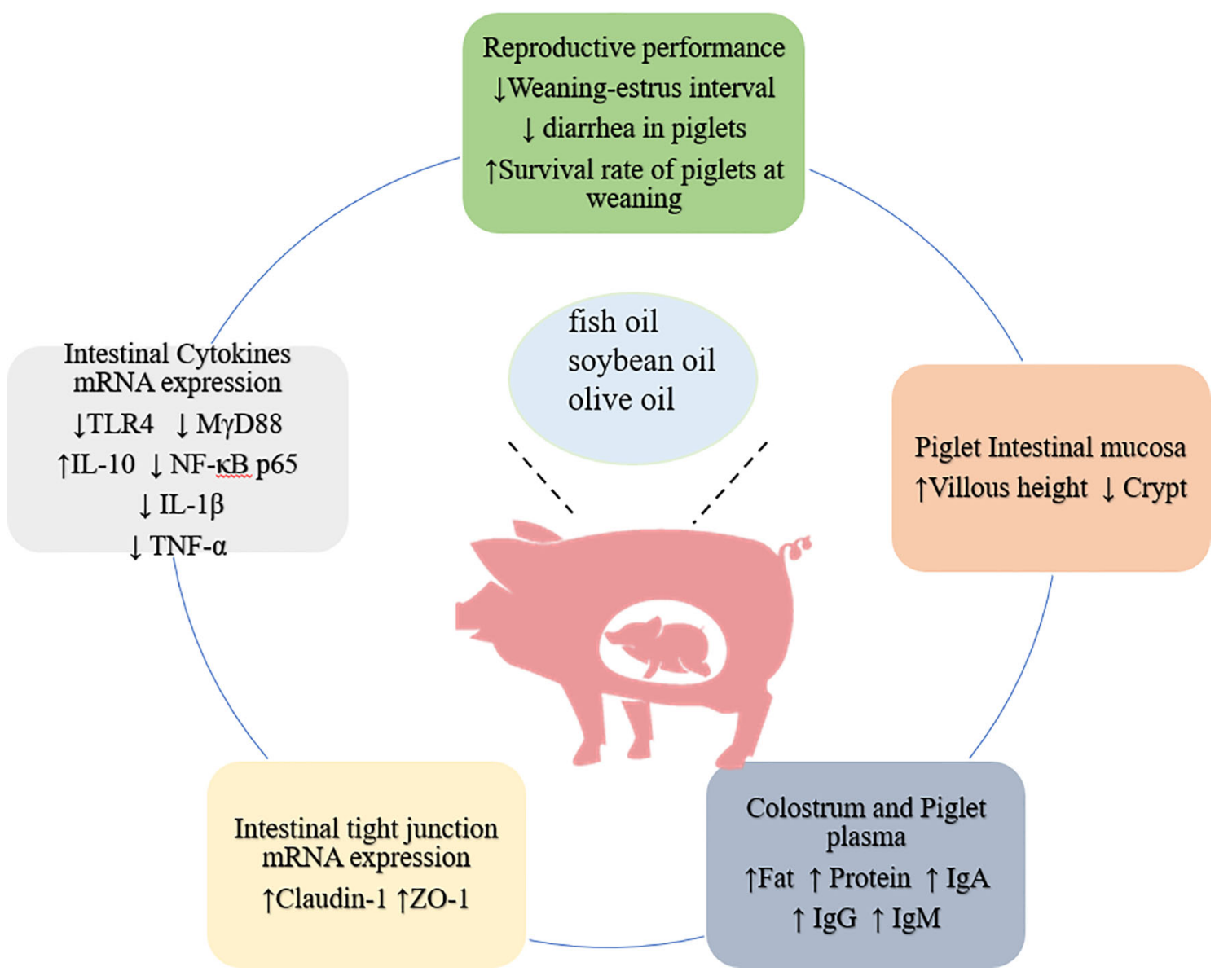

FIGURE 2 | Beneficial effects of adding fat in feed of pregnant sow on piglets.

Polyphenol is a bioactive substance with antioxidant, anticancer, anti-inflammatory and antibacterial properties (101). Supplementation of grape seed polyphenols (GSP) $(300 \mathrm{mg} / \mathrm{kg})$ during late pregnancy and lactation reduced the number of dead fetuses, improved farrowing and pre-weaning survival (91). This might due to GSP increased antioxidant ability, progesterone and estradiol levels as well as the content of colostral IgM and IgG in sow (91). Intriguingly, effects of GSP on colostral immunoglobin production is better than vitamin $\mathrm{E}$ (91). Supplementation herbal extracts during pregnancy and lactation also enhance the immune function and antioxidant capacity of next generation through maternal-offspring transmission. Forsythia suspensa extract (FSE) is a medicinal herb extract that mainly consists of forsythiaside A, forythialan A, phillyrin and phillygenin. FSE has been shown to perform antioxidant (102), intestinal microflora-regulating, and antiinflammatory effects (103). Dietary supplementation with FSE $(100 \mathrm{mg} / \mathrm{kg})$ in sows from the G85 to farrowing could upregulate the milk fat, milk protein and IgM level in colostrum, and increase the immune ability of the piglets (104). Mechanistically, FSE limits the inflammatory response with the inhibition of NF- $\mathrm{K} B$ signaling and the activation of Nrf2/HO-1 pathway
(105). In addition, GE has an anti-inflammatory effect by inhibiting the expression of chemokines (106). The sow feed GE could improve the content of antioxidant and phenolic compounds in piglets' plasma, and enhance the immune function by improve the concentration of $\operatorname{IgG}$ in colostrum and the plasma of the piglets (107). Resveratrol is a plant polyphenol with anti-inflammatory and antioxidant properties (108). Resveratrol $(300 \mathrm{mg} / \mathrm{kg})$ supplementation in sow diet improved the intestinal morphology and reduced intestinal inflammation as well as diarrhea in the offspring (109).

As an essential trace element for sows, selenium (Se) is incorporated into selenopsroteins and subsequently prevent intestinal inflammation by alleviating oxidative stress (110). In addition, selenoproteins such as glutathione peroxidase (GPX) and thioredoxin reductase (TXNRD) play an important role in the regulation of immune function (111). Organic Se compounds are more bioavailable than inorganic Se forms $(112,113)$. Supplementing sow gestation diets with HMSeBA $(0.3 \mathrm{mg} \mathrm{Se} /$ $\mathrm{kg}$ ) increases the expression of antioxidant-related selenoprotein genes in the placenta $(G P \times 2, G P \times 3)$ and liver of neonates (GPx1, GPX2, GPx3 and TXNRD2). Furthermore, administration of HMSeBA decreased the gene expression of $I L-1 \beta, I L-6$ and $I L-$ 
TABLE 3 | Maternal antioxidant and other substrates intake in the regulation of neonatal Infection, immunity and production performance.

\begin{tabular}{|c|c|c|c|c|c|}
\hline $\begin{array}{l}\text { Breed, feeding } \\
\text { time and products }\end{array}$ & $\begin{array}{l}\text { Reproductive and } \\
\text { lactation performance }\end{array}$ & $\begin{array}{l}\text { immune and oxidative } \\
\text { Stability of sows and piglets }\end{array}$ & Intestinal health & others & References \\
\hline $\begin{array}{l}\text { Breed: Large } \\
\text { White } \times \text { Landrace } \\
\text { period: G80-L21 } \\
\text { Product: grape } \\
\text { seed polyphenols } \\
(300 \mathrm{mg} / \mathrm{kg} \text { GSP) }\end{array}$ & $\begin{array}{l}\text { Reproductive performance } \\
\downarrow \text { dead fetuses: (1.19-0.63) } \\
\uparrow \text { Farrowing survival: (81.47-89.32\%) } \\
\text { Preweaning survivability: (91.85- } \\
95.23 \%) \\
\text { Colostrum } \\
\uparrow \text { lgM: (2.5-6 g/L) } \\
\text { lgG: (38-80 g/L) }\end{array}$ & $\begin{array}{l}\text { Sow plasma (G110) } \\
\uparrow S O D:(37.51-66.21 \mathrm{IU} / \mathrm{mL}) \\
\text { GSH-PX: }(417.83-620.33 \\
\mathrm{IU} / \mathrm{mL})\end{array}$ & N/A & $\begin{array}{l}\text { Sow plasma (G110) } \\
\uparrow P 4:(35-45 \mathrm{ng} / \mathrm{ml}) \\
\text { E2: }(40-50 \mathrm{pg} / \mathrm{ml})\end{array}$ & (91) \\
\hline $\begin{array}{l}\text { Breed: Landrace } \times \\
\text { Yorkshire } \\
\text { period: G85-L21 } \\
\text { Product: fully } \\
\text { oxidised } \beta \text {-carotene } \\
(8 \mathrm{mg} / \mathrm{kg})\end{array}$ & 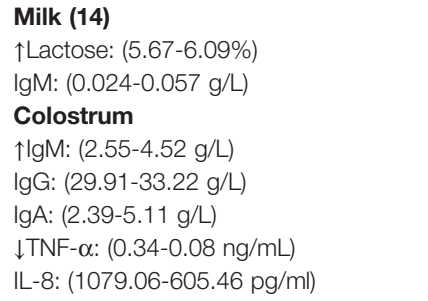 & N/A & N/A & N/A & (92) \\
\hline $\begin{array}{l}\text { Breed: Landrace } \times \\
\text { Yorkshire } \\
\text { period: G90-L21 } \\
\text { Product: Rare } \\
\text { Earth Elements } \\
(200 \text { mg REE } \\
\text { mixture/kg) }\end{array}$ & $\begin{array}{l}\text { Reproductive performance } \\
\text { \Within-litter birth weight CV: }(0.21- \\
0.18 \%) \\
\uparrow W e i g h t \text { at } 21 \text { st day: }(5.71-6.21 \mathrm{~kg}) \\
\text { Daily weight gain: }(223.06-241 . \\
75 \mathrm{~g} / \text { day) }\end{array}$ & $\begin{array}{l}\text { Sow plasma (farrowing) } \\
\uparrow G S H-P x:(650-700 \mathrm{U} / \mathrm{ml}) \\
\text { CAT: }(4.8-6.5 \mathrm{U} / \mathrm{mL}) \\
\downarrow T N F-\alpha:(200-130 \mathrm{pg} / \mathrm{ml}) \\
\text { Piglet plasma (weaning) } \\
\uparrow S O D:(120-130 \mathrm{U} / \mathrm{mL}) \\
\downarrow T N F-\alpha:(120-80 \mathrm{pg} / \mathrm{ml})\end{array}$ & $\begin{array}{l}\text { Fecal Microbiota (lactating } \\
\text { sows) } \\
\uparrow \text { Firmicutes: (78.2-81.0\%) } \\
\text { Bacteroidetes: (13-19.1\%) } \\
\text { Piglet Fecal Microbiota } \\
\text { (weaning) } \\
\downarrow \text { Proteobacteria phylum: } \\
(14.8-6.7 \%)\end{array}$ & $\begin{array}{l}\text { Piglet plasma } \\
\text { (weaning) } \\
\uparrow I G F-1:(180-210 \mathrm{ng} / \mathrm{ml})\end{array}$ & (93) \\
\hline $\begin{array}{l}\text { Breed: Large } \\
\text { White } \times \text { Landrace } \\
\text { period: G107-L21 } \\
\text { Product: vitamin E } \\
(250 \mathrm{IU} / \mathrm{kg})\end{array}$ & $\begin{array}{l}\text { Reproductive performance } \\
\uparrow B W \text { of weaned piglets:(4.89-5.67 kg) } \\
\text { Piglet Day 0-21 ADG: }(160-194 \mathrm{~g} / \mathrm{d}) \\
\text { Colostrum } \\
\uparrow F a t:(44 \cdot 35-53 \cdot 80 \mathrm{~g} / \mathrm{kg}) \\
\text { IgG: }(52 \cdot 78-63 \cdot 45 \mathrm{~g} / \mathrm{l}) \\
\text { IgA: }(8 \cdot 02-9 \cdot 01 \mathrm{~g} / \mathrm{l}) \\
\alpha \text {-tocopherol: }(18 \cdot 51-26 \cdot 97 \mu \mathrm{g} / \mathrm{l}) \\
\text { Milk } \\
\uparrow F a t:(67 \cdot 01-79 \cdot 13 \mathrm{~g} / \mathrm{kg}) \\
\text { IgG: }(0 \cdot 89-0 \cdot 96 \mathrm{~g} / \mathrm{l}) \\
\text { IgA: }(3 \cdot 81-4 \cdot 11 \mathrm{~g} / \mathrm{l}) \\
\alpha \text {-tocopherol: }(4.16-7.97 \mu \mathrm{g} / \mathrm{l})\end{array}$ & $\begin{array}{l}\text { Piglet plasma (L21) } \\
\uparrow \operatorname{lgG}(0 \cdot 44-0 \cdot 49 \mathrm{~g} / \mathrm{l}) \\
\operatorname{lgA}(0 \cdot 33-0 \cdot 36 \mathrm{~g} / \mathrm{l}) \\
\text { T-AOC }(6 \cdot 82-7 \cdot 65 \mathrm{IU} / \mathrm{ml}) \\
\text { CAT }(7 \cdot 38-8 \cdot 78 \mathrm{U} / \mathrm{ml})\end{array}$ & N/A & N/A & (94) \\
\hline $\begin{array}{l}\text { Breed: Yorkshire } \times \\
\text { Landrace } \\
\text { period: G75-L21 } \\
\text { Product: Taurine } \\
(1 \%)\end{array}$ & 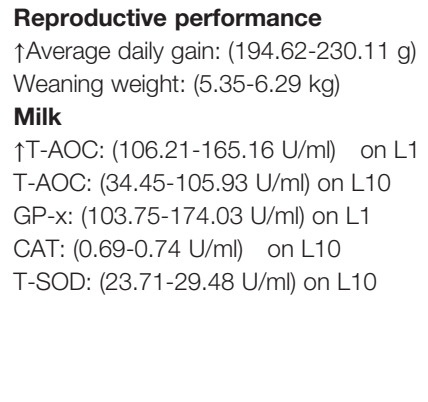 & $\begin{array}{l}\text { Piglet plasma (L1) } \\
\uparrow T-S O D:(35.53-104.92 \mathrm{U} / \mathrm{ml}) \\
\text { T-AOC: }(23.45-41.22 \mathrm{U} / \mathrm{ml}) \\
\text { CAT: }(0.34-0.38 \mathrm{U} / \mathrm{ml})\end{array}$ & 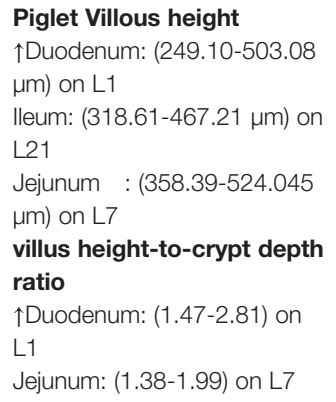 & N/A & (95) \\
\hline $\begin{array}{l}\text { Breed: Yorkshire } \times \\
\text { Landrace } \\
\text { period: G85-L21 } \\
\text { Product: lysozyme } \\
(300 \mathrm{~g} / \mathrm{t})\end{array}$ & $\begin{array}{l}\text { \Stillborn: (0.89-0.15) } \\
\text { Diarrhea rate: }(2.24-1.41 \%) \\
\text { Colostrum } \\
\uparrow l g A:(3.21-3.51 \mathrm{mg} / \mathrm{mL}) \\
\text { Milk (L7) } \\
\uparrow \operatorname{lgA}:(1.84-2.11 \mathrm{mg} / \mathrm{mL})\end{array}$ & $\begin{array}{l}\text { Sow plasma (L1) } \\
\uparrow \text { lgM: (0.81-0.98 mg/mL) } \\
\text { Piglet plasma (L21) } \\
\uparrow I L-10:(209.60-239.21 \mathrm{ng} / \mathrm{L}) \\
\text { lgA: }(2.16-2.56 \mathrm{mg} / \mathrm{mL}) \\
\text { lgG: }(2.25-2.65 \mathrm{mg} / \mathrm{mL}) \\
\text { lgM: }(23.98-28.87 \mathrm{mg} / \mathrm{mL})\end{array}$ & N/A & N/A & (96) \\
\hline $\begin{array}{l}\text { Period: G43- } \\
\text { weaning } \\
\text { Product: wheat } \\
\text { bran }(25 \% \text { of WB in }\end{array}$ & N/A & $\begin{array}{l}\text { Piglet Ileal mRNA } \\
\text { expression } \\
\uparrow P P A R \gamma:(1-1.37) \\
\text { IL6: }(0.61-1)\end{array}$ & $\begin{array}{l}\text { Piglet Small Intestine } \\
\uparrow \text { villi height: (380-450 } \mu \mathrm{m}) \\
\text { duodenum } \\
\text { villi/crypt: (1.4-2) duodenum }\end{array}$ & N/A & $(45)$ \\
\hline
\end{tabular}


TABLE 3 | Continued

\begin{tabular}{|c|c|c|c|c|c|}
\hline $\begin{array}{l}\text { Breed, feeding } \\
\text { time and products }\end{array}$ & $\begin{array}{c}\text { Reproductive and } \\
\text { lactation performance }\end{array}$ & $\begin{array}{l}\text { immune and oxidative } \\
\text { Stability of sows and piglets }\end{array}$ & Intestinal health & others & References \\
\hline $\begin{array}{l}\text { gestation and } 14 \% \\
\text { of WB in lactation.) }\end{array}$ & & & $\begin{array}{l}\text { villi/crypt: (1.4-1.6) jejunum } \\
\downarrow \text { crypts depth: (250-200 } \mu \mathrm{m}) \\
\text { jejunum }\end{array}$ & & \\
\hline $\begin{array}{l}\text { Breed: Large } \\
\text { White } \times \text { Landrace } \\
\text { Period: G85-L20 } \\
\text { Product: Yeast- } \\
\text { based nucleotide } \\
\text { (4 g YN/kg diet) }\end{array}$ & $\begin{array}{l}\text { Piglet at Weaning (D20) } \\
\text { 个litter size: }(9-10) \\
\text { ADG: }(190-200 \mathrm{~g}) \\
\text { Sow total milk yield: }(130-150 \mathrm{~kg})\end{array}$ & $\begin{array}{l}\text { Gene expression of } \\
\text { Intestinal cytokine } \\
\text { (neonatal piglets) } \\
\text { lleal } \\
\uparrow(\text { IL)-17: }(1-1.8) \\
\text { IL-8: }(1-1.5) \\
\text { TNF- } \alpha:(1-1.8) \\
\text { Jejunal } \\
\uparrow(\text { IL)-17: }(1-1.8) \\
\text { IL-6: }(1-2.5) \\
\text { IL-8: }(1-1.7) \\
\text { IFN- } \gamma:(1-1.6) \\
\text { TNF- } \alpha:(1-1.8) \\
\text { Duodenal } \\
\downarrow \| L-6:(1-0.5) \\
\uparrow \| L-1 \beta:(1-1.6)\end{array}$ & 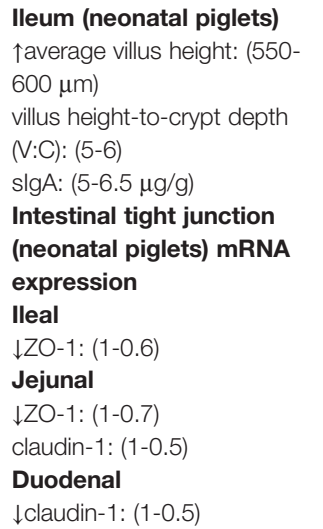 & $\begin{array}{l}\downarrow \text { Diarrhoea rate of } \\
\text { piglets: }(4.5-3 \%)\end{array}$ & (97) \\
\hline
\end{tabular}

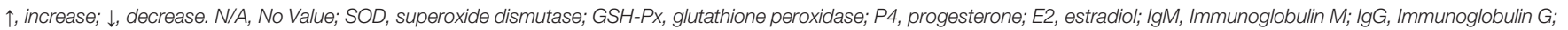

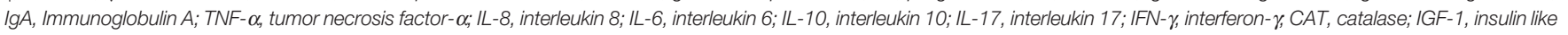
growth factor 1; T-AOC, total antioxidant capacity; T-SOD, total Superoxide dismutase; ZO-1, zonula occludens-1; IL-1 $\beta$, interleukin-1 $\beta$; ADG, average daily gain; slgA, secretedimmunoglobulin A; PPAR $\gamma$, peroxisome proliferator-activated receptor $\gamma$.

8 in placentas and IL- 6 serum concentration in neonatal piglets. Therefore, HMSeBA supplementation in sows during late pregnancy increased the antioxidant capacity of piglets and reduced maternal and fetal inflammation (114). Similarly, another study reported that HMSeBA $(0.3 \mathrm{mg} \mathrm{Se} / \mathrm{kg})$ supplementation to sows during pregnancy could up-regulate GPX1, GPX4 and selenoprotein expressions in the thymus and spleen of the offspring. Besides, the levels of inflammation, autophagy and endoplasmic reticulum stress were reduced, suggesting favorable outcomes in the immune function of offspring (115). Moreover, provision of maternal hydroxyselenomethionine (OH-SeMet) (0.3 mg Se/kg) during G84 to L21 showed a significantly increase of IgG level in piglets at weaning (2).

Taurine (Tau), a metabolite of methionine and cysteine, have anti-inflammatory and antioxidant properties $(116,117)$. Tau effectively promotes mammalian growth and intestinal development (118). Supplementation with Tau (1\%) in sow diets from G75 to weaning could significantly increase the activity of antioxidant enzymes (T-SOD, T-AOC, and CAT) in piglet serum and weaning body weight of the piglets. Besides, the height of jejunal villi, the ratio of villi height to crypt depth (VCR) and the expression of tight junction were also increased (95).

Oxidized $\beta$-carotene $(\mathrm{OxBC})$ is a complex mixture produced by complete and spontaneous oxidation of $\beta$-carotene. The addition of $\mathrm{OxBC}(8 \mathrm{mg} / \mathrm{kg})$ to the perinatal diet (G85-L21) improved the litter weight and individual body weight of the weaned piglets. This might be due to $\mathrm{OxBC}$ increased the immune status of sows, which further affect the growth of piglets. This is evidenced by decreased levels of cytokines (TNF- $\alpha$ and IL-18) and increased levels of immunoglobulin (IgM, IgA, and IgG) in colostrum (92).

\section{OTHER NUTRITIONAL STRATEGIES}

In this section, we describe some other nutrients which are advantageous to regulate the immunity and inflammation of piglets when supplemented in sow diets such as rare earth elements, lysozyme, and yeast nucleotides etc (Table 3).

Rare earth elements (REEs) includes 15 elements such as lanthanum (La) and cerium (Ce) (119). In addition to promote growth and feed conversion rate, rare earth elements also have anti-inflammatory and antioxidant properties (120, 121). A recent study showed that maternal supplementation with REEs $(200 \mathrm{mg} / \mathrm{kg}$ ) during late gestation could improve the antioxidant capacity and immune system through the up-regulation of serum CAT and GSH-Px level and downregulation of the serum TNF- $\alpha$ level of sow. In addition, piglets from REEs fed sow, have higher uniformity of birth weight and weaning weight, which might be related to the higher serum IGF-1 level (93). Furthermore, increased abundance of beneficial bacteria (Christensenellaceae and Ruminocococaceae) and decreased abundance of opportunistic pathogenic bacteria (Proteus and Campylobacter) were also found in the intestinal tract of piglets (93).

Lysozyme (LZM) is a natural antibacterial enzyme found in the tears, saliva and milk of mammals (122). Previous studies have shown that lysozyme has multiple beneficial effects on piglets, including improving intestinal morphology (123), regulating the intestinal microflora (124), and improving immunity (125). Sows fed diets containing lysozyme (300 g/t) from late gestation to weaning exhibited shorter weaning-estrous intervals and less stillbirths. In addition, serum IgM, IgA, IgG and IL-1 in sow were increased during lactation. Correspondingly, serum IgA, IgG, IgM, and IL-10 concentrations were also increased in piglet (96). Besides, piglets showed reduced rates of 
diarrhea, which may be due to a decreased number of campylobacter in the feces (126).

Nucleosides could promote the growth and development of intestinal epithelial cells (127). The addition of nucleotides to infant formula has a protective effect in preventing diarrhea and improving immunity (128). As a byproduct of yeast degradation, yeast-based nucleotides (YN) are rich in nucleotides. Supplementation of yeast cultures during pregnancy and lactation decrease of diarrhea and improve the growth performance of piglets (129). In detail,administration of yeast-based nucleotide (4 g YN/ $\mathrm{kg}$ ) during late pregnancy and lactation (G85-L20) of sow improved the development of intestinal morphology, and increased innate immunity with upregulation of intestinal IL-17, IL -8, IL - $1 \beta$, IL - 10 and TNF- $\alpha$ expressions in neonatal piglets (97).

Spray-dried plasma (SDP) is a protein-rich feed additive that contains immunoglobulins, peptides, glycoproteins and other active ingredients (130). Previous studies have shown that supplementation of SDP improved the immune response of pigs (131). From late pregnancy to weaning (G85-L27), maternal supplemented with $1 \%$ SDP reduced the serum concentrations of TNF- $\alpha$, TGF- $\beta 1$ and cortisol in sows and serum concentrations of TNF- $\alpha$, TGF- $\beta 1$ and cortisol in piglets. Additionally, the average daily gain of piglets at weaning was greater, and serum concentrations of cortisol, TGF- $\beta 1$, TNF- $\alpha$ and C- reactive protein were lower (132).

\section{CONCLUSION AND OUTLOOK}

Dietary fiber regulates inflammatory and immune response in the offspring by modulating the maternal intestinal microflora and milk immunoglobulin content. The antioxidant substances could directly react with the free radicals and enhance the maternal antioxidant capacity, thereby indirectly reducing infection in the offspring. The oil and fat products not only provide adequate energy to sows, but also supply functional fatty acids to alleviate infection and enhance the immune function in the offspring by exerting the anti-inflammatory and anti-oxidant effects. In summary, maternal nutrition intervention is an effective way to regulate the inflammatory response and immunity in the offspring.

In this review, we mainly focus on the positive effects of nutrients in the regulation of immunity and inflammatory response of sows and piglets during pregnancy and lactation. It worth noting that these effects would be affected by timing and/ or dosage of nutrient supplementation. Moreover, it is well known that excessive addition of fat usually has a negative effect on pigs. The toxic effects of excessive addition of other products, such as vitamin E and selenium (133) are also worthy of attention. Therefore, we have given the current dosage of these products. However, the adverse effects of excessive maternal supplementation of such products on the immune system of piglets still need further research. In addition, applying nutrients to piglets and sows at the same time during lactation could produce better results (93). Even though nutrient mixture might produce synergistic and addictive effects, but economic cost should be considered in pig production. Future study needs to identify the best time and dosage for nutrient supplementation in sow diet. In addition, current studies only observe the change of phenotypic indicators, in vitro cell experiments are required to clarify the potential mechanism. Lastly, whether the metabolites of these nutrients were involved in the regulation of immunity and inflammation in the offspring is still unclear and require more research.

\section{AUTHOR CONTRIBUTIONS}

QL, SZ, and MR initiated the idea, the scope, and the outline of this review paper. QL, SY, XZ, XL, ZW, YQ, WG, MR, and SZ studied and analyzed all of the publications cited in this paper and were involved in the manuscript preparation. SZ and MR conducted the final editing and proofreading. All authors contributed to the article and approved the submitted version.

\section{FUNDING}

This study was financially supported by the National Natural Science Foundation of the P.R. of China (No. 31872364 and No. 31802067), Guangdong Basic and Applied Basic Research Foundation (No. 2021A1515010440), Science and Technology Program of Guangzhou (No. 202102020056), Anhui Provincial Science and Technology Major Special Project (201903a06020002).

\section{REFERENCES}

1. Tuchscherer M, Otten W, Kanitz E, Gräbner M, Tuchscherer A, Bellmann O, et al. Effects of Inadequate Maternal Dietary Protein: Carbohydrate Ratios During Pregnancy on Offspring Immunity in Pigs. BMC Vet Res (2012) 8:1-11. doi: 10.1186/1746-6148-8-232

2. Li N-y, Sun Z-j, Ansari AR, Cui L, Hu Y-f, Li Z-w, et al. Impact of Maternal Selenium Supplementation From Late Gestation and Lactation on Piglet Immune Function. Biol Trace Elem Res (2020) 194:159-67. doi: 10.1007/ s12011-019-01754-y

3. Theil PK, Lauridsen C, Quesnel H. Neonatal Piglet Survival: Impact of Sow Nutrition Around Parturition on Fetal Glycogen Deposition and Production and Composition of Colostrum and Transient Milk. Animal (2014) 8:102130. doi: 10.1017/S1751731114000950

4. Dividich JL, Herpin P. Nutritional and Immunological Importance of Colostrum for the New-Born Pig. J Agric Sci (2005) 143:469-85. doi: 10.1017/S0021859605005642

5. Rooke JA, Bland IM. The Acquisition of Passive Immunity in the New-Born Piglet. Livest Prod Sci (2002) 78:13-23. doi: 10.1016/S0301-6226(02)00182-3

6. Nguyen TV, Yuan L, Azevedo MS, Jeong K-I, González A-M, Saif LJ. Transfer of Maternal Cytokines to Suckling Piglets: In Vivo and In Vitro Models With Implications for Immunomodulation of Neonatal Immunity. Vet Immunol Immunopathol (2007) 117:236-48. doi: 10.1016/j.vetimm.2007.02.013

7. Matamoros S, Gras-Leguen C, Le Vacon F, Potel G, de la Cochetiere M-F. Development of Intestinal Microbiota in Infants and its Impact on Health. Trends Microbiol (2013) 21:167-73. doi: 10.1016/j.tim.2012.12.001

8. Gomez-Gallego C, Garcia-Mantrana I, Salminen S, Collado MC. The Human Milk Microbiome and Factors Influencing Its Composition and 
Activity. Seminars in Fetal and Neonatal Medicine Vol. 21. Elsevier (2016) p. 400-5.

9. Rainone V, Schneider L, Saulle I, Ricci C, Biasin M, Al-Daghri N, et al. Upregulation of Inflammasome Activity and Increased Gut Permeability are Associated With Obesity in Children and Adolescents. Int J Obes (2016) 40:1026-33. doi: 10.1038/ijo.2016.26

10. Beloosesky R, Maravi N, Weiner Z, Khatib N, Awad N, Boles J, et al. Maternal Lipopolysaccharide-Induced Inflammation During Pregnancy Programs Impaired Offspring Innate Immune Responses. Am J Obstet Gynecol (2010) 203:185. doi: 10.1016/j.ajog.2010.04.033

11. Mor G, Aldo P, Alvero AB. The Unique Immunological and Microbial Aspects of Pregnancy. Nat Rev Immunol (2017) 17:469-82. doi: 10.1038/ nri.2017.64

12. Berchieri-Ronchi CB, Kim SW, Zhao Y, Correa CR, Yeum KJ, Ferreira A. Oxidative Stress Status of Highly Prolific Sows During Gestation and Lactation. Anim Int J Anim Biosci (2011) 5:1774-9. doi: 10.1017/S1751731111000772

13. Mudgil D, Barak S. Composition, Properties and Health Benefits of Indigestible Carbohydrate Polymers as Dietary Fiber: A Review. Int J Biol Macromol (2013) 61:1-6. doi: 10.1016/j.ijbiomac.2013.06.044

14. Shang Q, Liu H, Liu S, He T, Piao X. Effects of Dietary Fiber Sources During Late Gestation and Lactation on Sow Performance, Milk Quality, and Intestinal Health in Piglets. J Anim Sci (2019) 97:4922-33. doi: 10.1093/ jas/skz278

15. Fukuda S, Toh H, Hase K, Oshima K, Nakanishi Y, Yoshimura K, et al. Bifidobacteria can Protect From Enteropathogenic Infection Through Production of Acetate. Nature (2011) 469:543-7. doi: 10.1038/nature09646

16. Huang C, Song P, Fan P, Hou C, Thacker P, Ma X. Dietary Sodium Butyrate Decreases Postweaning Diarrhea by Modulating Intestinal Permeability and Changing the Bacterial Communities in Weaned Piglets. J Nutr (2015) 12:2774-80. doi: 10.3945/jn.115.217406

17. Fang C, Sun H, Wu J, Niu H, Feng J. Effects of Sodium Butyrate on Growth Performance, Haematological and Immunological Characteristics of Weanling Piglets. J Anim Physiol Anim Nutr (2014) 98:680-5. doi: 10.1111/jpn.12122

18. Nakajima A, Kaga N, Nakanishi Y, Ohno H, Miyamoto J, Kimura I, et al. Maternal High Fiber Diet During Pregnancy and Lactation Influences Regulatory T Cell Differentiation in Offspring in Mice. J Immunol (2017) 199:3516-24. doi: 10.4049/jimmunol.1700248

19. Gu XL, Song ZH, Li H, Wu S, Fan ZY. Effects of Dietary Isomaltooligosaccharide and Bacillus Spp. Supplementation During Perinatal Period on Lactational Performance, Blood Metabolites, and Milk Composition of Sows. J Sci Food Agric (2019) 99:5646-6653. doi: $10.1002 /$ jsfa. 9821

20. Wan J, Xu Q, He J. Maternal Chitosan Oligosaccharide Supplementation During Late Gestation and Lactation Affects Offspring Growth. Ital J Anim Sci (2018) 17:994-1000. doi: 10.1080/1828051X.2018.1435313

21. Shang Q, Liu S, Liu H, Mahfuz S, Piao X. Impact of Sugar Beet Pulp and Wheat Bran on Serum Biochemical Profile, Inflammatory Responses and Gut Microbiota in Sows During Late Gestation and Lactation. J Anim Sci Biotechnol (2021) 12:1-14. doi: 10.1186/s40104-021-00573-3

22. Heim, O'Doherty, O'Shea. Maternal Supplementation of Seaweed-Derived Polysaccharides Improves Intestinal Health and Immune Status of Suckling Piglets. J Nutr Sci (2015) 4:e27. doi: 10.1017/jns.2015.16

23. Leonard TSSG, Bahar B, Lynch BP, O'Doherty JV. Effect of Maternal Fish Oil and Seaweed Extract Supplementation on Colostrum and Milk Composition, Humoral Immune Response, and Performance of Suckled Piglets1. J Anim Sci (2010) 88:2988-97. doi: 10.2527/jas.2009-2764

24. Chuanshang C, Hongkui W, Chuanhui X, Xiaowei X, Siwen J, Jian P. Maternal Soluble Fiber Diet During Pregnancy Changes the Intestinal Microbiota, Improves Growth Performance, and Reduces Intestinal Permeability in Piglets. Appl Environ Microbiol (2018) 84:e01047-18. doi: 10.1128/AEM.01047-18

25. Duan X, Chen D, Zheng P, Tian G, Wang J, Mao X, et al. Effects of Dietary Mannan Oligosaccharide Supplementation on Performance and Immune Response of Sows and Their Offspring. Anim Feed Sci Technol (2016) 218:17-25. doi: 10.1016/j.anifeedsci.2016.05.002

26. Ho T, Jahan M, Haque Z, Kracht S, Wang B. Maternal Chitosan Oligosaccharide Intervention Optimizes the Production Performance and
Health Status of Gilts and Their Offspring. Anim Nutr (2020) 6:134-42. doi: 10.1016/j.aninu.2020.02.001

27. Wu Y, Pan L, Shang Q, Ma X, Long S, Xu Y, et al. Effects of IsomaltoOligosaccharides as Potential Prebiotics on Performance, Immune Function and Gut Microbiota in Weaned Pigs. Anim Feed Sci Technol (2017) 230:12635. doi: 10.1016/j.anifeedsci.2017.05.013

28. Patel S, Goyal A. Functional Oligosaccharides: Production, Properties and Applications. World J Microbiol Biotechnol (2011) 27:1119-28. doi: 10.1007/ s11274-010-0558-5

29. Zhang L, Wang J, Liao S, Duan Y, Gu X, Li H, et al. Effects of Dietary Isomaltooligosaccharide Levels on the Gut Microbiota, Immune Function of Sows and the Diarrhea Rate of Their Offspring. Front Microbiol (2020) 11:3425. doi: 10.3389/fmicb.2020.588986

30. Li J, Tan B, Mai K. Dietary Probiotic Bacillus OJ and Isomaltooligosaccharides Influence the Intestine Microbial Populations, Immune Responses and Resistance to White Spot Syndrome Virus in Shrimp (Litopenaeus Vannamei). Aquaculture (2009) 291:35-40. doi: 10.1016/j.aquaculture.2009.03.005

31. Yen MT, Yang JH, Mau JL. Antioxidant Properties of Chitosan From Crab Shells. Carbohydr Polym (2008) 74:840-4. doi: 10.1016/j.carbpol.2008.05.003

32. Ma P, Liu HT, Wei P, Xu QS, Bai XF, Du YG, et al. Chitosan Oligosaccharides Inhibit LPS-Induced Over-Expression of IL-6 and TNF$\alpha$ in RAW264. 7 Macrophage Cells Through Blockade of Mitogen-Activated Protein Kinase (MAPK) and PI3K/Akt Signaling Pathways. Carbohydr Polym (2011) 84:1391-8. doi: 10.1016/j.carbpol.2011.01.045

33. Duan X, Tian G, Chen D, Yang J, Zhang L, Li B, et al. Effects of Diet Chitosan Oligosaccharide on Performance and Immune Response of Sows and Their Offspring. Livest Sci (2020) 239:104114. doi: 10.1016/j.livsci.2020.104114

34. Gómez B, Gullón B, Yáñez R, Schols H, Alonso JL. Prebiotic Potential of Pectins and Pectic Oligosaccharides Derived From Lemon Peel Wastes and Sugar Beet Pulp: A Comparative Evaluation. J Funct Foods (2016) 20:108-21. doi: 10.1016/j.jff.2015.10.029

35. Tan C, Wei H, Ao J, Long G, Jian P. Inclusion of Konjac Flour in the Gestation Diet Changes the Gut Microbiota, Alleviates Oxidative Stress, and Improves Insulin Sensitivity in Sows. Appl Environ Microbiol (2016) 82:5899. doi: 10.1128/AEM.01374-16

36. Gahan DA, Lynch MB, Callan JJ, O'Sullivan J, O'Doherty J. Performance of Weanling Piglets Offered Low-, Medium- or High-Lactose Diets Supplemented With a Seaweed Extract From Laminaria Spp. Animal (2009) 3:24-31. doi: 10.1017/S1751731108003017

37. Pluske JR, Hampson DJ, Williams IH. Factors Influencing the Structure and Function of the Small Intestine in the Weaned Pig: A Review. Livest Prod Sci (1997) 51:215-36. doi: 10.1016/S0301-6226(97)00057-2

38. Leonard SG, Sweeney T, Bahar B, O'Doherty JV. Effect of Maternal Seaweed Extract Supplementation on Suckling Piglet Growth, Humoral Immunity, Selected Microflora, and Immune Response After an Ex Vivo Lipopolysaccharide Challenge. J Anim Sci (2012) 90:505-14. doi: 10.2527/ jas.2010-3243

39. Sweeney T, Collins C, Reilly P, Pierce K, Ryan M, O'doherty J. Effect of Purified $\beta$-Glucans Derived From Laminaria Digitata, Laminaria Hyperborea and Saccharomyces Cerevisiae on Piglet Performance, Selected Bacterial Populations, Volatile Fatty Acids and Pro-Inflammatory Cytokines in the Gastrointestinal Tract of Pigs. Br J Nutr (2012) 108:122634. doi: 10.1017/S0007114511006751

40. Fuongfuchat A, Seetapan N, Makmoon T, Pongjaruwat W, Methacanon P, Gamonpilas C. Linear and Non-Linear Viscoelastic Behaviors of Crosslinked Tapioca Starch/Polysaccharide Systems. J Food Eng (2012) 109:571-8. doi: 10.1016/j.jfoodeng.2011.10.022

41. Spring P, Wenk C, Connolly A, Kiers A. A Review of 733 Published Trials on Bio-Mos ${ }^{\circledR}$, a Mannan Oligosaccharide, and Actigen ${ }^{\circledR}$, a Second Generation Mannose Rich Fraction, on Farm and Companion Animals. J Appl Anim Nutr (2015) 3:e8. doi: 10.1017/jan.2015.6

42. Duan X, Tian G, Chen D, Huang L, Yu B. Mannan Oligosaccharide Supplementation in Diets of Sow and (or) Their Offspring Improved Immunity and Regulated Intestinal Bacteria in Piglet. J Anim Sci (2019) 97:4548-56. doi: 10.1093/jas/skz318

43. Jarrett S, Ashworth CJ. The Role of Dietary Fibre in Pig Production, With a Particular Emphasis on Reproduction. J Anim Sci Biotechnol (2018) 9:1-11. doi: 10.1186/s40104-018-0270-0 
44. Onipe OO, Jideani AI, Beswa D. Composition and Functionality of Wheat Bran and its Application in Some Cereal Food Products. Int J Food Sci Technol (2015) 50:2509-18. doi: 10.1111/ijfs.12935

45. Leblois J, Zhang Y, Wavreille J, Uerlings J, Everaert N. Effects of Wheat Bran Applied to Maternal Diet on the Intestinal Architecture and Immune Gene Expression in Suckling Piglets. Animals (2020) 10:2051. doi: 10.3390/ ani10112051

46. Agyekum AK, Nyachoti CM. Nutritional and Metabolic Consequences of Feeding High-Fiber Diets to Swine: A Review. Engineering (2017) 3:716-25. doi: 10.1016/J.ENG.2017.03.010

47. Wenk C. The Role of Dietary Fibre in the Digestive Physiology of the Pig. Anim Feed Sci Technol (2001) 90:21-33. doi: 10.1016/S0377-8401(01)00194-8

48. Rosero DS, Boyd RD, Odle J, Heugten EV. Optimizing Dietary Lipid Use to Improve Essential Fatty Acid Status and Reproductive Performance of the Modern Lactating Sow: A Review. J Anim Sci Biotechnol (2016) 7:1-18.

49. Tilton LS, Miller SP. Addition of Fat to the Diets of Lactating Sows: I. Effects on Milk Production and Composition and Carcass Composition of the Litter at Weaning. J Anim Sci (1999) 77:2491-500. doi: 10.2527/1999.7792491x

50. Jin C, Fang Z, Lin Y, Che L, Wu C, Xu S, et al. Influence of Dietary Fat Source on Sow and Litter Performance, Colostrum and Milk Fatty Acid Profile in Late Gestation and Lactation. Anim Sci J (2017) 88:1768-78. doi: 10.1111/ asj. 12836

51. Liu Y. Fatty Acids, Inflammation and Intestinal Health in Pigs. J Anim Sci Biotechnol (2015) 6(1):321-9. doi: 10.1186/s40104-015-0040-1

52. Che L, Liu P, Yang Z, Che L, Hu L, Qin L, et al. Maternal High Fat Intake Affects the Development and Transcriptional Profile of Fetal Intestine in Late Gestation Using Pig Model. Lipids Health Dis (2016) 15:90. doi: 10.1186/s12944-016-0261-0

53. Shen Y, Wan H, Zhu J, Fang Z, Che L, Xu S, et al. Fish Oil and Olive Oil Supplementation in Late Pregnancy and Lactation Differentially Affect Oxidative Stress and Inflammation in Sows and Piglets. Lipids (2015) 50:647-58. doi: 10.1007/s11745-015-4024-x

54. Jones G, Edwards S, Sinclair A, Gebbie F, Rooke J, Jagger S, et al. The Effect of Maize Starch or Soya-Bean Oil as Energy Sources in Lactation on Sow and Piglet Performance in Association With Sow Metabolic State Around Peak Lactation. Anim Sci (2002) 75:57-66. doi: 10.1017/S1357729800052838

55. Knazek RA, Liu SC, Bodwin JS, Vonderhaar BK. Requirement of Essential Fatty Acids in the Diet for Development of the Mouse Mammary Gland. J Natl Cancer Inst (1980) 64:377-82. doi: 10.1093/jnci/64.2.377

56. Peng X, Yan C, Hu L, Liu Y, Xu Q, Wang R, et al. Effects of Fat Supplementation During Gestation on Reproductive Performance, Milk Composition of Sows and Intestinal Development of Their Offspring. Animals (Basel) (2019) 9:125. doi: 10.3390/ani9040125

57. Calder PC. Polyunsaturated Fatty Acids, Inflammation, and Immunity. Lipids (2001) 36:1007-24. doi: 10.1007/s11745-001-0812-7

58. Luo J, Huang F, Xiao C, Chen W, Jiang S, Peng J. Effect of Dietary Supplementation of Fish Oil for Lactating Sows and Weaned Piglets on Piglet Th Polarization. Livest Sci (2009) 126:286-91. doi: 10.1016/ j.livsci.2009.08.002

59. Schellingerhout A.B. Influence of Dietary (n-3) Polyunsaturated Acids, in the Form of Either Linseed or Fish Oil, on Growth Performance, Small Intestinal Morphology and Essential Fatty Acid Status of Weanling Piglets PhD Dissertation. Netherlands: University of Utretch (2002).

60. Rooke J, Shanks M, Edwards S. Effect of Offering Maize, Linseed or Tuna Oils Throughout Pregnancy and Lactation on Sow and Piglet Tissue Composition and Piglet Performance. Anim Sci (2000) 71:289-99. doi: 10.1017/S1357729800055132

61. Gaines A, Carroll J, Yi G, Allee G, Zannelli M. Effect of Menhaden Fish Oil Supplementation and Lipopolysaccharide Exposure on Nursery Pigs: II. Effects on the Immune Axis When Fed Simple or Complex Diets Containing No Spray-Dried Plasma. Domest Anim Endocrinol (2003) 24:353-65. doi: 10.1016/S0739-7240(03)00016-X

62. Jin C, Fang Z, Lin Y, Che L, Wu C, Xu S, et al. Influence of Dietary Fat Source on Sow and Litter Performance, Colostrum and Milk Fatty Acid Profile in Late Gestation and Lactation. Anim Sci J (2017) 88:1768-78. doi: 10.1111/ asj. 12836

63. Mitre R, Etienne M, Martinais S, Salmon H, Allaume P, Legrand P, et al. Humoral Defence Improvement and Haematopoiesis Stimulation in Sows and Offspring by Oral Supply of Shark-Liver Oil to Mothers During Gestation and Lactation. Br J Nutr (2005) 94:753-62. doi: 10.1079/ BJN20051569

64. Luo W, Luo Z, Xu X, Zhao S, Li S, Sho T, et al. The Effect of Maternal Diet With Fish Oil on Oxidative Stress and Inflammatory Response in Sow and New-Born Piglets. Oxid Med Cell Longev (2019) 2019:6765803. doi: 10.1155/ 2019/6765803

65. Luo J, Huang F, Xiao C, Fang Z, Peng J, Jiang S. Responses of Growth Performance and Proinflammatory Cytokines Expression to Fish Oil Supplementation in Lactation Sows' and/or Weaned Piglets' Diets. BioMed Res Int (2013) 2013:905918. doi: 10.1155/2013/905918

66. Shen Y, Wan H, Zhu J, Fang Z, Che L, Xu S, et al. Fish Oil and Olive Oil Supplementation in Late Pregnancy and Lactation Differentially Affect Oxidative Stress and Inflammation in Sows and Piglets. Lipids (2015) 50:647-58. doi: 10.1007/s11745-015-4024-x

67. Tanghe S, Missotten J, Raes K, De Smet S. The Effect of Different Concentrations of Linseed Oil or Fish Oil in the Maternal Diet on the Fatty Acid Composition and Oxidative Status of Sows and Piglets. J Anim Physiol Anim Nutr (2015) 99:938-49. doi: 10.1111/jpn.12243

68. Cools A, Maes D, Papadopoulos G, Vandermeiren JA, Meyer E, Demeyere $\mathrm{K}$, et al. Dose-Response Effect of Fish Oil Substitution in Parturition Feed on Erythrocyte Membrane Characteristics and Sow Performance. J Anim Physiol Anim Nutr (2011) 95:125-36. doi: 10.1111/j.1439-0396.2010.01119.x

69. Chen J, Xu Q, Li Y, Tang Z, Sun W, Zhang X, et al. Comparative Effects of Dietary Supplementations With Sodium Butyrate, Medium-Chain Fatty Acids, and N-3 Polyunsaturated Fatty Acids in Late Pregnancy and Lactation on the Reproductive Performance of Sows and Growth Performance of Suckling Piglets. J Anim Sci (2019) 97:4256-67. doi: $10.1093 /$ jas/skz284

70. Lauridsen C, Stagsted J, Jensen SK. N- 6 and N- 3 Fatty Acids Ratio and Vitamin E in Porcine Maternal Diet Influence the Antioxidant Status and Immune Cell Eicosanoid Response in the Progeny. Prostaglandins Other Lipid Mediat (2007) 84:66-78. doi: 10.1016/j.prostaglandins.2007.04.003

71. Yao W, Li J, jun Wang J, Zhou W, Wang Q, Zhu R, et al. Effects of Dietary Ratio of N-6 to N-3 Polyunsaturated Fatty Acids on Immunoglobulins, Cytokines, Fatty Acid Composition, and Performance of Lactating Sows and Suckling Piglets. J Anim Sci Biotechnol (2012) 3:1-8. doi: 10.1186/20491891-3-43

72. Mataix J, Battino M, Ramirez-Tortosa MC, Bertoli E, Quiles JL. Virgin Olive Oil: A Key Healthy Component of the Mediterranean Diet. Mediterr J Nutr Metab (2008) 1:69. doi: 10.3233/s12349-008-0012-5

73. Cheng Z. Antimicrobial, Antioxidant and Anti-Inflammatory Phenolic Activities in Extra Virgin Olive Oil. Food Sci Technol (2012) 23:129-35. doi: 10.1016/j.copbio.2011.09.006

74. Diep TA, Madsen AN, Holst B, Kristiansen MM, Wellner N, Hansen SH, et al. Dietary Fat Decreases Intestinal Levels of the Anorectic Lipids Through a Fat Sensor. FASEB J (2011) 25:765-74. doi: 10.1096/fj.10-166595

75. Cheng $\mathrm{C}, \mathrm{Wu} \mathrm{X}$, Zhang X, Zhang X, Peng J. Obesity of Sows at Late Pregnancy Aggravates Metabolic Disorder of Perinatal Sows and Affects Performance and Intestinal Health of Piglets. Animals (2020) 10:49. doi: 10.3390/ani10010049

76. Zhou Y, Xu T, Cai A, Wu Y, Wei H, Jiang S, et al. Excessive Backfat of Sows at $109 \mathrm{D}$ of Gestation Induces Lipotoxic Placental Environment and is Associated With Declining Reproductive Performance. J Anim Sci (2018) 96:250-7. doi: 10.1093/jas/skx041

77. Wilson RM, Messaoudi I. The Impact of Maternal Obesity During Pregnancy on Offspring Immunity. Mol Cell Endocrinol (2015) 418:13442. doi: 10.1016/j.mce.2015.07.028

78. Jarvie E, Hauguel-de-Mouzon S, Nelson SM, Sattar N, Catalano PM, Freeman DJ. Lipotoxicity in Obese Pregnancy and its Potential Role in Adverse Pregnancy Outcome and Obesity in the Offspring. Clin Sci (2010) 119:123-9. doi: 10.1042/CS20090640

79. Saben J, Lindsey F, Zhong Y, Thakali K, Badger TM, Andres A, et al. Maternal Obesity is Associated With a Lipotoxic Placental Environment. Placenta (2014) 35:171-7. doi: 10.1016/j.placenta.2014.01.003

80. Challier J, Basu S, Bintein T, Minium J, Hotmire K, Catalano P, et al. Obesity in Pregnancy Stimulates Macrophage Accumulation and Inflammation in the Placenta. Placenta (2008) 29:274-81. doi: 10.1016/j.placenta.2007.12.010 
81. Oliva K, Barker G, Riley C, Bailey MJ, Permezel M, Rice GE, et al. The Effect of Pre-Existing Maternal Obesity on the Placental Proteome: TwoDimensional Difference Gel Electrophoresis Coupled With Mass Spectrometry. J Mol Endocrinol (2012) 48:139-49. doi: 10.1530/JME-110123

82. Zhou Y, Xu T, Wu Y, Wei H, Peng J. Oxidative Stress and Inflammation in Sows With Excess Backfat: Up-Regulated Cytokine Expression and Elevated Oxidative Stress Biomarkers in Placenta. Animals (2019) 9:796. doi: 10.3390/ ani9100796

83. Xue Y, Wang H, Du M, Zhu M-J. Maternal Obesity Induces Gut Inflammation and Impairs Gut Epithelial Barrier Function in Nonobese Diabetic Mice. J Nutr Biochem (2014) 25:758-64. doi: 10.1016/j.jnutbio. 2014.03.009

84. Innis SM, Dai C, Wu X, Buchan AM, Jacobson K. Perinatal Lipid Nutrition Alters Early Intestinal Development and Programs the Response to Experimental Colitis in Young Adult Rats. Am J Physiol Gastrointest Liver Physiol (2010) 299:G1376-85. doi: 10.1152/ajpgi.00258.2010

85. Tan C, Wei H, Ao J, Long G, Peng J. Inclusion of Konjac Flour in the Gestation Diet Changes the Gut Microbiota, Alleviates Oxidative Stress, and Improves Insulin Sensitivity in Sows. Appl Environ Microbiol (2016) 82:5899-909. doi: 10.1128/AEM.01374-16

86. Pereira AC, Martel F. Oxidative Stress in Pregnancy and Fertility Pathologies. Cell Biol Toxicol (2014) 30:301-12. doi: 10.1007/s10565-0149285-2

87. Casanueva E, Viteri FE. Iron and Oxidative Stress in Pregnancy. J Nutr (2003) 133:1700S-8S. doi: 10.1093/jn/133.5.1700S

88. Chaudhari N, Talwar P, Parimisetty A, Lefebvre d'Hellencourt C, Ravanan P. A Molecular Web: Endoplasmic Reticulum Stress, Inflammation, and Oxidative Stress. Front Cell Neurosci (2014) 8:213. doi: 10.3389/ fncel.2014.00213

89. Bunders MJ, van Hamme JL, Jansen MH, Boer K, Kootstra NA, Kuijpers TW. Fetal Exposure to HIV-1 Alters Chemokine Receptor Expression by CD4+ T Cells and Increases Susceptibility to HIV-1. Sci Rep (2014) 4:1-8. doi: $10.1038 /$ srep 06690

90. Hong M, Sandalova E, Low D, Gehring AJ, Fieni S, Amadei B, et al. Trained Immunity in Newborn Infants of HBV-Infected Mothers. Nat Commun (2015) 6:1-12. doi: 10.1038/ncomms7588

91. Wang X, Jiang G, Kebreab E, Yu Q, Li J, Zhang X, et al. Effects of Dietary Grape Seed Polyphenols Supplementation During Late Gestation and Lactation on Antioxidant Status in Serum and Immunoglobulin Content in Colostrum of Multiparous Sows. J Anim Sci (2019) 97:2515-23. doi: $10.1093 / \mathrm{jas} / \mathrm{skz} 128$

92. Chen J, Chen J, Zhang Y, Lv Y, Qiao H, Tian M, et al. Effects of Maternal Supplementation With Fully Oxidised Beta-Carotene on the Reproductive Performance and Immune Response of Sows, as Well as the Growth Performance of Nursing Piglets. Br J Nutr (2021) 125:62-70. doi: 10.1017/ S0007114520002652

93. Xiong Y, Jiaman P, Liangkang L, Yujun W, Shimeng H, Zhi F, et al. Effects of Maternal Supplementation With Rare Earth Elements During Late Gestation and Lactation on Performances, Health, and Fecal Microbiota of the Sows and Their Offspring. Animals (2019) 9:738. doi: 10.3390/ani9100738

94. Lin W, Xiaodong X, Ge S, Baoming S, Anshan S. High Concentration of Vitamin E Supplementation in Sow Diet During the Last Week of Gestation and Lactation Affects the Immunological Variables and Antioxidative Parameters in Piglets. J Dairy Res (2017) 84:8-13. doi: 10.1017/ S0022029916000650

95. Xu M, Che L, Gao K, Wang L, Yang X, Wen X, et al. Effects of Dietary Taurine Supplementation to Gilts During Late Gestation and Lactation on Offspring Growth and Oxidative Stress. Animals (Basel) (2019) 9:220. doi: 10.3390/ani9050220

96. Xu SY, Shi JK, Shi XL, Dong YP, Shen YP. Effects of Dietary Supplementation With Lysozyme During Late Gestation and Lactation Stage on the Performance of Sows and Their Offspring. J Anim Sci (2018) 96:4768-79. doi: 10.1093/jas/sky338

97. Gao L, Xie C, Liang X, Li Z, Yin Y. Yeast-Based Nucleotide Supplementation in Mother Sows Modifies the Intestinal Barrier Function and Immune Response of Neonatal Pigs. Anim Nutr (2021) 7:84-93. doi: 10.1016/ j.aninu.2020.06.009
98. Brennan LA, Morris GM, Wasson GR, Hannigan BM, Barnett YA. The Effect of Vitamin C or Vitamin E Supplementation on Basal and H2O2Induced DNA Damage in Human Lymphocytes. Br J Nutr (2000) 84:195202. doi: $10.1017 /$ S0007114500001422

99. Hidiroglou M, Batra T, Farnworth E, Markham F. Effect of Vitamin E Supplementation on Immune Status and $\alpha$-Tocopherol in Plasma of Piglets. Reprod Nutr Dev (1995) 35:443-50. doi: 10.1051/rnd:19950409

100. Hayek MG, Mitchell GE, Harmon RJ, Stahly TS, Cromwell GL, Tucker RE, et al. Porcine Immunoglobulin Transfer After Prepartum Treatment With Selenium or Vitamin E. J Anim Sci (1989) 67:1299-306. doi: 10.2527/ jas1989.6751299x

101. Zhang H, Tsao R. Dietary Polyphenols, Oxidative Stress and Antioxidant and Anti-Inflammatory Effects. Curr Opin Food Sci (2016) 8:33-42. doi: 10.1016/ j.cofs.2016.02.002

102. Han X, Piao X, Zhang H, Li P, Yi J, Zhang Q, et al. Forsythia Suspensa Extract has the Potential to Substitute Antibiotic in Broiler Chicken. Asian-Australas J Anim Sci (2012) 25:569. doi: 10.5713/ajas.2011.11425

103. Zhao P, Piao X, Zeng Z, Li P, Xu X, Wang H. Effect of Forsythia Suspensa Extract and Chito-Oligosaccharide Alone or in Combination on Performance, Intestinal Barrier Function, Antioxidant Capacity and Immune Characteristics of Weaned Piglets. Anim Sci J (2017) 88:854-62. doi: 10.1111/asj.12656

104. Long S, Wu D, He T, Piao X. Dietary Supplementation With Forsythia Suspensa Extract During Late Gestation Improves Reproductive Performance, Colostrum Composition, Antioxidant Status, Immunoglobulin, and Inflammatory Cytokines in Sows and Newborn Piglets. Anim Feed Sci Technol (2021) 271:114700. doi: 10.1016/ j.anifeedsci.2020.114700

105. Wang Y, Zhao H, Lin C, Ren J, Zhang S. Forsythiaside A Exhibits AntiInflammatory Effects in LPS-Stimulated BV2 Microglia Cells Through Activation of Nrf2/HO-1 Signaling Pathway. Neurochem Res (2016) 41:659-65. doi: 10.1007/s11064-015-1731-x

106. Phan PV, Sohrabi A, Polotsky A, Hungerford DS, Lindmark L, Frondoza CG. Ginger Extract Components Suppress Induction of Chemokine Expression in Human Synoviocytes. J Altern Complement Med (2005) 11:149-54. doi: 10.1089/acm.2005.11.149

107. Lee SD, Kim JH, Jung HJ, Kim YH, Kim IC, Kim SB, et al. The Effect of Ginger Extracts on the Antioxidant Capacity and IgG Concentrations in the Colostrum and Plasma of Neo-Born Piglets and Sows. Livest Sci (2013) 154:117-22. doi: 10.1016/j.livsci.2013.02.001

108. Meng Q, Guo T, Li G, Sun S, He S, Cheng B, et al. Dietary Resveratrol Improves Antioxidant Status of Sows and Piglets and Regulates Antioxidant Gene Expression in Placenta by Keap1-Nrf2 Pathway and Sirt1. J Anim Sci Biotechnol (2018) 9:1-13. doi: 10.1186/s40104-018-0248-y

109. Meng Q, Sun S, He S, Shi B, Shan A, Cheng B. Maternal Dietary Resveratrol Alleviates Weaning-Associated Intestinal Inflammation and Diarrhea in Porcine Offspring by Altering Intestinal Gene Expression and Microbiota. Food Funct (2019) 10:5626-43. doi: 10.1039/C9FO00637K

110. Short SP, Pilat JM, Williams CS. Roles for Selenium and Selenoprotein P in the Development, Progression, and Prevention of Intestinal Disease. Free Radical Biol Med (2018) 127:26-35. doi: 10.1016/j.freeradbiomed.2018. 05.066

111. Avery JC, Hoffmann PR. Selenium, Selenoproteins, and Immunity. Nutrients (2018) 10:1203. doi: 10.3390/nu10091203

112. Briens M, Mercier Y, Rouffineau F, Mercerand F, Geraert P-A. 2-Hydroxy-4Methylselenobutanoic Acid Induces Additional Tissue Selenium Enrichment in Broiler Chickens Compared With Other Selenium Sources. Poult Sci (2014) 93:85-93. doi: 10.3382/ps.2013-03182

113. Couloigner F, Jlali M, Briens M, Rouffineau F, Geraert P-A, Mercier Y. Selenium Deposition Kinetics of Different Selenium Sources in Muscle and Feathers of Broilers. Poult Sci (2015) 94:2708-14. doi: 10.3382/ps/pev282

114. Mou D, Ding D, Yan H, Qin B, Dong Y, Li Z, et al. Maternal Supplementation of Organic Selenium During Gestation Improves Sows and Offspring Antioxidant Capacity and Inflammatory Status and Promotes Embryo Survival. Food Funct (2020) 11:7748-61. doi: 10.1039/D0FO00832J

115. Ding D, Mou D, Zhao L, Jiang X, Che L, Fang Z, et al. Maternal Organic Selenium Supplementation Alleviates LPS Induced Inflammation, Autophagy and ER Stress in the Thymus and Spleen of Offspring Piglets 
by Improving the Expression of Selenoproteins. Food Funct (2021) 12:11214-28. doi: 10.1039/D1FO01653A

116. Lourenço R, Camilo ME. Taurine: A Conditionally Essential Amino Acid in Humans? An Overview in Health and Disease. Nutr Hosp (2002) 17:262.

117. Winiarska K, Szymanski K, Gorniak P, Dudziak M, Bryla J. Hypoglycaemic, Antioxidative and Nephroprotective Effects of Taurine in Alloxan Diabetic Rabbits. Biochimie (2009) 91:261-70. doi: 10.1016/j.biochi.2008.09.006

118. Sukhotnik I, Aranovich I, Shahar YB, Bitterman N, Pollak Y. Effect of Taurine on Intestinal Recovery Following Intestinal Ischemia-Reperfusion Injury in a Rat. Pediatr Surg Int (2016) 32:161-8. doi: 10.1007/s00383-015-3828-3

119. Bruce DW, Hietbrink BE, Dubois KP. The Acute Mammalian Toxicity of Rare Earth Nitrates and Oxides. Toxicol Appl Pharmacol (1963) 5:750-9. doi: 10.1016/0041-008X(63)90067-X

120. Kraatz M, Taras D, Männer K, Simon O. Weaning Pig Performance and Faecal Microbiota With and Without in-Feed Addition of Rare Earth Elements. J Anim Physiol Anim Nutr (2010) 90:361-8. doi: 10.1111/j.14390396.2005.00594.x

121. Fei G, Guo X, Xie A, Yuan LL, Wang Y. The Suppressive Effects of Lanthanum on the Production of Inflammatory Mediators in Mice Challenged by LPS. Biol Trace Elem Res (2011) 142:693-703. doi: 10.1007/s12011-010-8792-0

122. Masschalck B, Michiels CW. Antimicrobial Properties of Lysozyme in Relation to Foodborne Vegetative Bacteria. Crit Rev Microbiol (2003) 29:191-214. doi: 10.1080/713610448

123. Oliver WT, Wells JE. Lysozyme as an Alternative to Antibiotics Improves Growth Performance and Small Intestinal Morphology in Nursery Pigs. J Anim Sci (2013) 91:191-214. doi: 10.2527/jas.2012-5782

124. Cooper CA, Garas K, Maga EA, Murray JD, Riccardo M. Consuming Transgenic Goats' Milk Containing the Antimicrobial Protein Lysozyme Helps Resolve Diarrhea in Young Pigs. PloS One (2013) 8:e58409. doi: 10.1371/journal.pone.0058409

125. Nyachoti CM, Kiarie E, Bhandari SK, Zhang G, Krause DO. Weaned Pig Responses to Escherichia Coli K88 Oral Challenge When Receiving a Lysozyme Supplement. J Anim Sci (2012) 90:252. doi: 10.2527/jas.2010-3596

126. Wells JE, Berry ED, Kalchayanand N, Rempel LA, Kim M, Oliver WT. Effect of Lysozyme or Antibiotics on Faecal Zoonotic Pathogens in Nursery Pigs. J Appl Microbiol (2015) 118:1489-97. doi: 10.1111/jam.12803

127. Uauy R, Stringel G, Thomas R, Quan R. Effect of Dietary Nucleosides on Growth and Maturation of the Developing Gut in the Rat. J Pediatr Gastroenterol Nutr (1990) 10:497-503. doi: 10.1097/00005176-199005000-00014
128. Hess JR, Greenberg NA. The Role of Nucleotides in the Immune and Gastrointestinal Systems: Potential Clinical Applications. Nutr Clin Pract (2012) 27:281. doi: 10.1177/0884533611434933

129. Hung I. The Effect of Dietary Nucleotides in Sow and Nursery Piglet Diets on Reproduction, Growth, and Immune Response (2015). Dissertations \& Theses - Gradworks University of Kentucky.

130. Pettigrew J. Reduced Use of Antibiotic Growth Promoters in Diets Fed to Weanling Pigs: Dietary Tools, Part 1. Anim Biotechnol (2006) 17:207-15. doi: 10.1080/10495390600956946

131. Bosi P, Casini L, Finamore A, Cremokolini C, Merialdi G, Trevisi P, et al. Spray-Dried Plasma Improves Growth Performance and Reduces Inflammatory Status of Weaned Pigs Challenged With Enterotoxigenic Escherichia Coli K88. J Anim Sci (2004) 82:1764-72. doi: 10.2527/2004. $8261764 x$

132. Kim K, Kim B, Kyoung H, Liu Y, Campbell JM, Song M, et al. Dietary SprayDried Plasma Supplementation in Late-Gestation and Lactation Enhanced Productive Performance and Immune Responses of Lactating Sows and Their Litters. J Anim Sci Technol (2021) 63:1076. doi: 10.5187/jast.2021.e83

133. Poulsen HD, Danielsen V, Nielsen TK, Wolstrup C. Excessive Dietary Selenium to Primiparous Sows and Their Offspring. Acta Vet Scand (1989) 30:371-8. doi: 10.1186/BF03548012

Conflict of Interest: The authors declare that the research was conducted in the absence of any commercial or financial relationships that could be construed as a potential conflict of interest.

Publisher's Note: All claims expressed in this article are solely those of the authors and do not necessarily represent those of their affiliated organizations, or those of the publisher, the editors and the reviewers. Any product that may be evaluated in this article, or claim that may be made by its manufacturer, is not guaranteed or endorsed by the publisher.

Copyright $\odot 2022 \mathrm{Li}$, Yang, Zhang, Liu, Wu, Qi, Guan, Ren and Zhang. This is an open-access article distributed under the terms of the Creative Commons Attribution License (CC BY). The use, distribution or reproduction in other forums is permitted, provided the original author(s) and the copyright owner(s) are credited and that the original publication in this journal is cited, in accordance with accepted academic practice. No use, distribution or reproduction is permitted which does not comply with these terms. 